\title{
Soil chemical legacies trigger species-specific and context- dependent root responses in later arriving plants
}

Benjamin M. Delory ${ }^{1}$, Hannes Schempp ${ }^{1}$, Sina Maria Spachmann ${ }^{1}$, Laura Störzer ${ }^{1}$, Nicole M. van Dam²,3, Vicky M. Temperton ${ }^{1}$, Alexander Weinhold ${ }^{2,3}$

\footnotetext{
${ }^{1}$ Ecosystem Functioning and Services, Institute of Ecology, Leuphana University Lüneburg, Germany

${ }^{2}$ Molecular Interaction Ecology, German Centre for Integrative Biodiversity Research (iDiv) Halle-JenaLeipzig, Leipzig, Germany

${ }^{3}$ Institute of Biodiversity, Friedrich Schiller University Jena, Jena, Germany
}

Corresponding author: Benjamin M. Delory

Email: Benjamin.Delory@leuphana.de, Delory.Benjamin@gmail.com

\begin{tabular}{cc}
\hline Authors & ORCID \\
\hline Benjamin M. Delory & $0000-0002-1190-8060$ \\
Alexander Weinhold & $0000-0003-1418-7788$ \\
Nicole M. van Dam & $0000-0003-2622-5446$ \\
Vicky M. Temperton & $0000-0003-0543-4521$ \\
\hline
\end{tabular}




\section{Abstract}

Soil legacies play an important role for the creation of priority effects. However, we still poorly understand to what extent the metabolome found in the soil solution of a plant community is conditioned by its species composition and whether soil chemical legacies affect subsequent species during assembly. To test these hypotheses, we collected soil solutions from forb or grass communities and evaluated how the metabolome of these soil solutions affected the growth, biomass allocation, and functional traits of a forb (Dianthus deltoides) and a grass species (Festuca rubra). Results showed that the metabolomes found in the soil solutions of forb and grass communities differed in composition and chemical diversity. While soil chemical legacies did not have any effect on $F$. rubra, root foraging by $D$. deltoides decreased when plants received the soil solution from a grass or a forb community. Structural equation modelling showed that reduced soil exploration by $D$. deltoides arose via either a root growthdependent pathway (forb metabolome) or a root trait-dependent pathway (grass metabolome). Reduced root foraging was not connected to a decrease in total $\mathrm{N}$ uptake. Our findings reveal that soil chemical legacies can create belowground priority effects by affecting root foraging in later arriving plants.

Key words: niche modification, plant-soil interactions, priority effect mechanism, root exudates, root traits, untargeted metabolomics. 
bioRxiv preprint doi: https://doi.org/10.1101/2020.09.01 276840; this version posted October 16, 2020. The copyright holder for this preprint (which was not certified by peer review) is the author/funder, who has granted bioRxiv a license to display the preprint in perpetuity. It is made available under aCC-BY 4.0 International license.

\section{Introduction}

Assembly history is an important determinant of the structure and functioning of ecological communities (Chase 2003; Fukami et al. 2010; Halliday et al. 2020), and plant communities are no exception (Werner, Vaughn, Stuble, Wolf \& Young 2016). The sequence and timing of multiple biotic and abiotic events that happened in the past cause plant communities to be historically contingent (Temperton, Baasch, von Gillhaussen \& Kirmer 2016; Werner, Stuble, Groves \& Young 2020). This historical contingency is often caused by priority effects, in which the order and timing of species immigration influence further assembly by determining the way species affect one another in communities (Fukami 2015). Typically, priority effects occur when early arrival of species at a site affects the growth, development, and/or reproduction of species arriving later (Hess et al. 2020). Priority effects are known to influence the structure, but also the functioning of plant communities. For instance, plant order of arrival has been shown to modulate aboveground and belowground productivity (Körner, Stöcklin, Reuther-Thiébaud \& Pelaez-Riedl 2008; Weidlich et al. 2017, 2018), biodiversity patterns (Martin \& Wilsey 2012; Wilsey, Barber \& Martin 2015), exotic and native species dominance (Grman \& Suding 2010; Stuble \& Souza 2016; Delory, Weidlich, Kunz, Neitzel \& Temperton 2019b), as well as the mechanisms of grassland overyielding in mixed communities (Delory, Weidlich, von Gillhaussen \& Temperton 2019a). Although more research is necessary to determine how long priority effects can persist, there is now strong evidence that priority effects can lead to alternative vegetation states that differ in both structure and function (Weidlich et al. 2020; Wilsey 2020).

Priority effects most likely arise from a diversity of mechanisms operating simultaneously. In a nichebased framework, mechanisms creating priority effects can be categorized into niche preemption and niche modification (Fukami 2015). Niche preemption occurs when early-arriving species decrease the availability of essential resources such as space, light, and soil nutrients for species arriving later. If niche preemption is the main force creating priority effects, the growth and development of late-arriving species can only be negatively impacted by early species (Fukami 2015). Niche modification, however, occurs when early-arriving species affect the identity of the species able to further colonise the community by modifying the types of niches available for late-arriving species. Depending on the biological mechanism(s) responsible for niche modification, late-arriving species can either be inhibited or facilitated by early-arriving species (Fukami 2015; Delory et al. 2019a). Although niche preemption plays an important role in the creation of priority effects in plant communities (Kardol, Souza \& Classen 
bioRxiv preprint doi: https://doi.org/10.1101/2020.09.01 276840; this version posted October 16, 2020. The copyright holder for this preprint (which was not certified by peer review) is the author/funder, who has granted bioRxiv a license to display the preprint in perpetuity. It is made available under aCC-BY 4.0 International license.

2013), the relative importance of niche modification mechanisms in creating priority effects certainly deserves more attention (Halliday et al. 2020; Solarik, Cazelles, Messier, Bergeron \& Gravel 2020).

So far, niche modification-driven priority effects in plant communities have been studied mainly in the context of plant-soil feedback (PSF) experiments (Bever et al. 2010; van der Putten et al. 2013). When plant species arrive early at a site, they will alter the biotic and abiotic components of the soil environment and create soil legacies that might affect early species performance (often negatively) as well as the growth and development of species arriving later during succession (Klironomos 2002; Bever 2003; Grman \& Suding 2010). Previous studies showed that early-arriving species can induce soil legacy effects through changes in the composition of soil microbial communities (e.g., accumulation of pathogenic fungi), which can then contribute to historical contingency effects by altering competitive relationships in plant communities (Kardol, Cornips, van Kempen, Bakx-Schotman \& van der Putten 2007; Heinen et al. 2020). However, due to the strong interlinkage between microbial communities living in the rhizosphere and metabolites exuded by plant roots, biotic PSF effects are tightly associated with root exudation (Mommer, Kirkegaard \& van Ruijven 2016; Sasse, Martinoia \& Northen 2018; Korenblum et al. 2020).

Root exudates mediate complex belowground interactions between plants and soil organisms (Delory, Delaplace, Fauconnier \& du Jardin 2016; van Dam \& Bouwmeester 2016; Sasse et al. 2018). They also impact on the functioning of ecosystems, notably through their effect on soil microbial activity (Lange et al. 2015), soil carbon dynamics (de Vries et al. 2019; Henneron, Cros, Picon-Cochard, Rahimian \& Fontaine 2020), plants' response to environmental stress (Williams \& de Vries 2019), nutrient cycling, and soil aggregate stability (Bardgett, Mommer \& de Vries 2014; Mommer et al. 2016; Oburger \& Jones 2018). A number of studies have demonstrated the importance of root exudates in creating soil legacies. A first line of evidence comes from studies showing that root-exuded metabolites are able to shape rhizospheric bacterial and fungal communities (Eisenhauer et al. 2017; Sasse et al. 2018). This change in rhizosphere microbiota can then trigger PSF responses on plant growth and defence (Hu et al. 2018). A second line of evidence comes from studies showing that root-secreted allelochemicals can suppress the growth of neighbours (Callaway \& Aschehoug 2000; Bertin, Yang \& Weston 2003; Perry, Alford, Horiuchi, Paschke \& Vivanco 2007), and that root exudates can act as chemical cues for neighbour detection and recognition (Kong et al. 2018; Wang, Kong, Wang \& Meiners 2020). Root exudates can not only provide information about the identity of a neighbour growing in the vicinity of a focal plant, but 
they can also carry information about the population origin of a neighbour and its degree of genetic relatedness to the focal plant (Biedrzycki, Jilany, Dudley \& Bais 2010; Semchenko, Saar \& Lepik 2014). Despite this body of evidence supporting the central role of root exudates in structuring the rhizosphere microbiome and mediating plant-plant interactions, we still do not know to what extent soil chemical legacies can affect the growth and development of later arriving plant individuals and contribute to the creation of priority effects in plant communities.

In the context of this paper, soil chemical legacies should be understood as legacies associated with the set of organic chemicals (or metabolome) present in the soil solution of an established plant community that late species will have to face when they attempt to colonise that community. This includes all the soluble organic compounds of low and high molecular weight released into the soil solution by living plant roots (root exudates) and microorganisms, senescing and dead root or microbial cells, as well as decomposing soil organic matter. Therefore, it encompasses all the metabolites originating from dead and living plant roots and their associated symbionts (rhizodeposition), but also all the metabolites released into the soil solution by microorganisms (Oburger \& Schmidt 2016; Oburger \& Jones 2018).

In this study, we investigated to what extent the composition of the metabolome found in the soil solution of a plant community depends on its species composition, and how strongly soil chemical legacies can affect later arriving plants. Considering that the composition of the metabolome found in the soil solution is dynamic, species-specific, and strongly dependent on ambient environmental conditions (Oburger \& Jones 2018; Sasse et al. 2018; Williams \& de Vries 2019), we first hypothesise that the composition and chemical diversity of the soil solution's metabolome depends on the species composition of the early-arriving species group (e.g., after a disturbance). Second, we hypothesise that soil chemical legacies can create priority effects by affecting the growth, biomass allocation, and/or functional traits of later arriving plants. We predict that late-arriving species will be more affected by soil chemical legacies created by a plant community composed of functionally similar species to itself. This prediction is consistent with the limiting similarity hypothesis rooted in community invasibility research (MacArthur \& Levins 1967; Fargione, Brown \& Tilman 2004). 
bioRxiv preprint doi: https://doi.org/10.1101/2020.09.01.276840; this version posted October 16, 2020. The copyright holder for this preprint (which was not certified by peer review) is the author/funder, who has granted bioRxiv a license to display the preprint in perpetuity. It is made available under aCC-BY 4.0 International license.

\section{Materials and Methods}

In order to test if soil chemical legacies can affect later arriving plants and play a role in the creation of priority effects, we set up an experiment consisting of two different phases: (1) collecting soil solution from plant communities differing in species composition (forbs or grasses), and (2) evaluating the effect of the metabolomes found in the collected soil solutions on the growth, biomass allocation, and functional traits of late arriving plant individuals (Fig. 1).
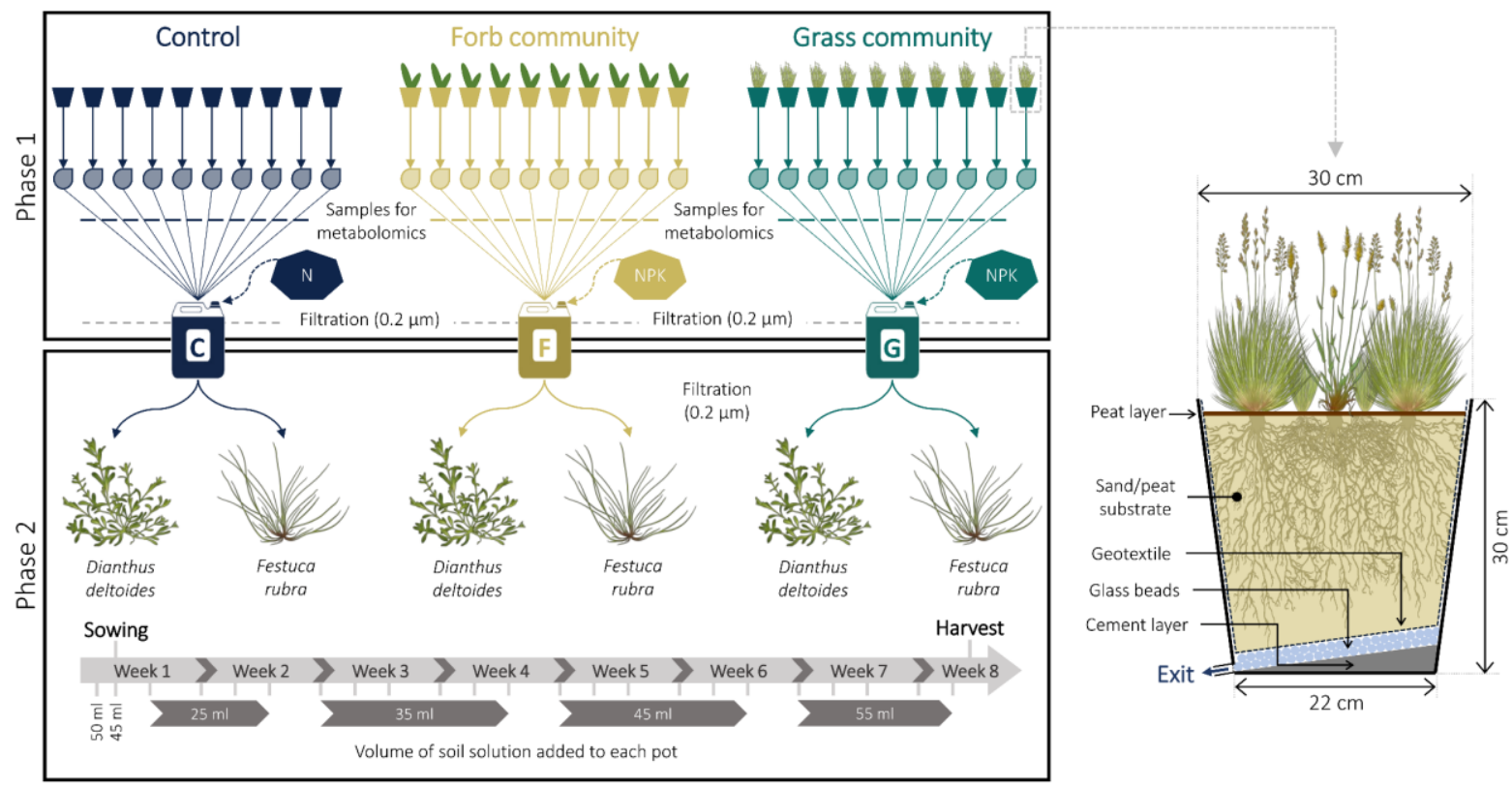

Fig. 1 Schematic overview of the experiment designed to test if soil chemical legacies can affect later arriving plants and contribute to the creation of priority effects. The experiment consisted of two successive phases: collecting soil solution from plant communities differing in species composition, plus controls with soil only (phase 1), and evaluating the effect of the metabolome contained in the collected soil solutions on the growth, biomass allocation, and functional traits of $D$. deltoides and $F$. rubra (phase 2). A schematic description of the mesocosms used for the first phase of the experiment is provided on the right side of the figure.

\section{Phase 1: Collection of the soil solution from different plant communities}

Thirty mesocosms were engineered to facilitate the frequent sampling of soil solution (Fig. 1). A cement layer with a slope directing the percolating soil solution towards an outlet valve was added at the bottom of each pot. This cement layer was painted (Aryl liquid plastic 2668, Renovo) and a polyester resin (Resinpal 1719, Resinpal) was applied at the junction between the cement layer and pot walls. All mesocosms were filled with $1 \mathrm{~kg}$ of $1 \mathrm{~cm}$-diameter glass beads and $15 \mathrm{~kg}$ of a $5 \mathrm{~mm}$-sieved mixture of sand $(90 \%, v / v)$ and peat $(10 \%, v / v)$. Before adding the substrate, a water-permeable geotextile was added inside the pots. Ten days later, 10 mesocosms were sown with a mixture of four grass species 
bioRxiv preprint doi: https://doi.org/10.1101/2020.09.01.276840; this version posted October 16,2020 . The copyright holder for this preprint (which was not certified by peer review) is the author/funder, who has granted bioRxiv a license to display the preprint in perpetuity. It is made available under aCC-BY 4.0 International license.

(Grasses: Festuca rubra, Festuca ovina, Anthoxanthum odoratum, Corynephorus canescens), 10 were sown with a mixture of four forb species (Forbs: Pilosella officinarum, Arenaria serpyllifolia, Silene vulgaris, Dianthus deltoides), and 10 were left unsown (CTL). Seed mixtures were calculated to reach a planting density of 80 individuals per species and per pot. Because of a strong dominance of $S$. vulgaris in forb communities, 40 individuals of that species were removed from each mesocosm in the first two months. All pots were regularly watered with an equal volume of tap water throughout the duration of the experiment.

Soil solution sampling started 65 days after sowing and was repeated two times a week for five weeks. Soil solution samples were collected using a protocol similar to the one described in Semchenko et al. (2014). At each sampling date, each mesocosm was watered with tap water and $200 \mathrm{ml}$ of soil solution leaching out of the pots was collected. In order to get the required amount of soil solution, the volume of tap water added at the top of the soil had to be adjusted for each treatment (Grasses > Forbs $>C T L$ ). Directly after collection, soil solution samples were stored in a cool box. For each treatment, all samples collected from different mesocosms and at different time points were pooled in large canisters and stored in the dark at $-20^{\circ} \mathrm{C}$. For each treatment, $20 \mathrm{I}$ of soil solution was collected over the entire duration of the experiment $(0.2 \mathrm{I} \times 10$ mesocosms $\times 10$ sampling points $)$. Once a week, soil solution and tap water (Tap) samples were also collected for chemical analyses. Particulates and microorganisms were removed from the three soil solutions by filtration (pore size: $0.2 \mu \mathrm{m}$; MSR TrailShot, MSR) and the nutrient content of each solution was analysed (Raiffeisen-Laborservice, Ormont, Germany). As expected, $\mathrm{NO}_{3}{ }^{-}, \mathrm{PO}_{4}^{3-}$ and $\mathrm{K}^{+}$concentrations were lower in soil solutions from grass and forb communities (Fig. S1). Analyses did not show any difference in micronutrient concentrations between soil solutions. To minimise differences in macronutrient concentrations, $\mathrm{Ca}\left(\mathrm{NO}_{3}\right)_{2} \cdot 4 \mathrm{H}_{2} \mathrm{O}$ was added to the solution collected from unsown mesocosms $\left(6.2 \mathrm{mg} \mathrm{l}^{-1}\right)$, whereas $\mathrm{KNO}_{3}$ and $\mathrm{KH}_{2} \mathrm{PO}_{4}$ were added to the solutions collected from forb (22.5 $\mathrm{mg} \mathrm{l}^{-1} \mathrm{KNO}_{3}$ and $\left.0.7 \mathrm{mg} \mathrm{l}^{-1} \mathrm{KH}_{2} \mathrm{PO}_{4}\right)$ and grass communities (21.7 $\mathrm{mg} \mathrm{l}^{-1} \mathrm{KNO}_{3}$ and $0.8 \mathrm{mg} \mathrm{l}^{-1} \mathrm{KH}_{2} \mathrm{PO}_{4}$ ). After addition of these salts, all solutions had very similar macronutrient concentrations (Fig. S1).

This first phase of the experiment was performed in a greenhouse located in Lüneburg (Lower Saxony, Germany). The temperature inside the greenhouse was $25.2 \pm 6.2^{\circ} \mathrm{C}$ during the day and $19.3 \pm 3.2^{\circ} \mathrm{C}$ during the night. 
bioRxiv preprint doi: https://doi.org/10.1101/2020.09.01 276840; this version posted October 16, 2020. The copyright holder for this preprint (which was not certified by peer review) is the author/funder, who has granted bioRxiv a license to display the preprint in perpetuity. It is made available under aCC-BY 4.0 International license.

\section{Metabolomic fingerprinting of soil solution samples}

During phase 1, soil solution samples for chemical analyses were collected from 30 mesocosms at five different time points and stored at $-20^{\circ} \mathrm{C}$ until further processing. For each mesocosm, a composite soil solution was created by pooling aliquots $(8 \mathrm{ml})$ collected at each time point. Composite soil solutions were then filtered using syringe filters equipped with a cellulose acetate membrane (pore size: $0.2 \mu \mathrm{m}$ ) to remove particulates and microorganisms. The concentration of dissolved organic carbon (DOC) in composite soil solutions was measured using a TOC analyser (iso TOC Cube; Elementar, Langenselbold, Germany). The samples were enriched according to a method modified from Strehmel et al. (2014). Soil solutions were evaporated in falcon tubes until dryness using a freeze dryer. The residue was then suspended in $2 \mathrm{ml}$ water/methanol $(95 / 5, \mathrm{v} / \mathrm{v})$. The samples were sonicated at ambient temperature for $10 \mathrm{~min}$ and the supernatant was transferred to a $2 \mathrm{ml}$ Safe-Lock tube. After $10 \mathrm{~min}$ of centrifugation at $6000 \mathrm{~g}, 1.5 \mathrm{ml}$ of the sample solution was loaded on a SPE cartridge (Chromabond® C18 Hydra; bed weight, $200 \mathrm{mg}$; capacity, $3 \mathrm{ml}$; Marcherey-Nagel) that was previously conditioned with $1 \mathrm{ml}$ pure methanol and $1 \mathrm{ml}$ water/formic acid $(98 / 2, \mathrm{v} / \mathrm{v})$. The cartridge was washed with $1 \mathrm{ml}$ pure water and samples were eluted with $1 \mathrm{ml}$ methanol/formic acid (98/2, v/v) into $2 \mathrm{ml}$ Safe-Lock tubes. The samples were reduced to dryness in a vacuum centrifuge at $40^{\circ} \mathrm{C}$ and reconstituted in $150 \mu \mathrm{l}$ methanol/water $(70 / 30, \mathrm{v} / \mathrm{v})$. After sonication for $10 \mathrm{~min}$ at ambient temperature and centrifugation for $10 \mathrm{~min}$ at $6000 \mathrm{~g}$, the supernatant was transferred to a glass vial and subjected to Liquid Chromatography-Time of Flight-Mass Spectrometry (LC-qToF-MS) analysis.

Enriched soil solution samples were run twice on LC-qToF-MS and were analysed with an Ultimate 3000 UHPLC system (Thermo Scientific Dionex) equipped with an Acclaim RSLC 120 column (150×2.1 $\mathrm{mm}$; particle size, $2.2 \mu \mathrm{m}$; Thermo Fischer Scientific) using the following gradient at a flow rate of 0.5 $\mathrm{ml} \mathrm{min}{ }^{-1}: 0-2$ min isocratic 95\% A (water/formic acid, 99.95/0.05, v/v) and 5\% B (acetonitrile/formic acid, 99.95/0.05, v/v); 2-12 min, linear from $5 \%$ to $45 \% \mathrm{~B} ; 12-19 \mathrm{~min}$, linear from $45 \%$ to $95 \% \mathrm{~B} ; 19-22 \mathrm{~min}$, isocratic $95 \% \mathrm{~B} ; 22-25 \mathrm{~min}$, linear from $95 \%$ to $5 \% \mathrm{~B} ; 25-30 \mathrm{~min}$, isocratic $5 \% \mathrm{~B}$. Compounds were detected with a maXis impact qToF-MS (Bruker Daltonics, Bremen, Germany) applying the following conditions in negative and positive mode: scan range, 50-1400 m/z; acquisition rate, $3 \mathrm{~Hz}$; end plate offset, $-500 \mathrm{~V}$; capillary voltage, $3500 \mathrm{~V}$ (positive) or $2500 \mathrm{~V}$ (negative); nebulizer pressure, 3 bar (positive) or 2.5 bar (negative); dry gas, $11 \mathrm{I} \mathrm{min}^{-1}$; dry temperature, $240^{\circ} \mathrm{C}$ (positive) or $220^{\circ} \mathrm{C}$ (negative). Mass calibration was performed using sodium formate clusters (10 mM solution of $\mathrm{NaOH}$ in 
$50 / 50(\mathrm{v} / \mathrm{v})$ isopropanol/water containing $0.2 \%$ formic acid). Every ten samples, a mixture of all the samples (Mix) was injected as a quality control sample.

\section{Processing of raw LC-MS data}

The LC-qToF-MS raw data were converted to the mzXML format using the CompassXport utility of the Data Analysis software (Bruker Daltonics). Peak picking, feature alignment and feature grouping was done in R 3.6.0 (R Core Team 2019) using the Bioconductor (Huber et al. 2015) packages 'xcms' v1.52.0 (Smith, Want, O'maille, Abagyan \& Siuzdak 2006; Tautenhahn, Bottcher \& Neumann 2008; Benton, Want \& Ebbels 2010) and 'CAMERA' v1.32.0 (Kuhl, Tautenhahn, Böttcher, Larson \& Neumann 2012). For raw data pre-processing with 'xcms' and 'CAMERA', all samples were organized into five groups, according to their origin: Forbs, Grasses, CTL, Tap water, or Mix. The following 'xcms' parameters were applied: peak picking method 'centWave' (snthr = 50; ppm = 5; peakwidth $=4,10$ ); peak grouping method 'density' $(\operatorname{minfrac}=0.5 ; \mathrm{bw}=3 ; \mathrm{mzwid}=0.05)$; retention time correction method 'peakgroups' (family = symmetric). CAMERA was used to annotate adducts, fragments, and isotope peaks with the following parameters: extended rule set (https://github.com/stanstrup/commonMZ/tree/master/inst/extdata); perfwhm = 0.6; calclso = TRUE; calcCaS $=$ TRUE. CAMERA additionally sorted these adducts/fragments into pseudo compound (PC) groups where each group potentially represents a metabolite. Lastly, each PC group (hereafter referred to as 'metabolite') was collapsed using an in-house maximum heuristic approach aiming to find the feature that most often displayed the highest intensity values across all samples for each PC group (Ristok et al. 2019). In our analysis, each PC group was therefore represented by one feature with a known mass-to-charge ratio $(\mathrm{mz})$ and retention time $(\mathrm{rt})$.

Following this first processing step, features with a constant or single value across samples were removed from the dataset. Using the missForest R package (Stekhoven \& Bühlmann 2012), missing values were imputed using a random forest algorithm (500 trees). This imputation method has been shown to outperform other methods commonly used for LC-MS metabolomics data (Kokla, Virtanen, Kolehmainen, Paananen \& Hanhineva 2019). Peak intensity values were then normalized based on DOC values and transformed using a generalized logarithmic transformation. 
bioRxiv preprint doi: https://doi.org/10.1101/2020.09.01 276840; this version posted October 16, 2020. The copyright holder for this preprint (which was not certified by peer review) is the author/funder, who has granted bioRxiv a license to display the preprint in perpetuity. It is made available under aCC-BY 4.0 International license.

\section{Analysis of differences in metabolome composition and chemical diversity}

The analysis of a biological or environmental sample using an untargeted metabolomics approach often results in the detection of a very high number of unknown chemical compounds for which reference data (i.e., fully identified compounds) are not available (Da Silva, Dorrestein \& Quinn 2015; Uthe et al. 2021). Therefore, rather than focusing on metabolite identification, the analyses reported in this paper focus on the detection of differences in composition and chemical diversity between soil solution samples (metabolomic fingerprinting). Considering that one of the main aims of our experiment was to determine if the composition of the metabolome found in the soil solution of plant communities was dependent on its species composition, we argue that the methodological approach described below is well suited to answer our research question.

Differences in metabolome composition between soil solution samples were visualised using principal component analysis (Lê, Josse \& Husson 2008). Positive and negative ionisation data were merged for multivariate statistical analysis. Detection of the most discriminant metabolites was performed using a random forest approach (Liaw \& Wiener 2002). First, a random forest model was fitted to metabolomics data using 1000 trees and a combination of model hyperparameters that minimised the out-of-bag (OOB) error (mtry=150, nodesize $=1$, sampsize $=23$; OOB error rate: $3.45 \%$ ). Second, the most discriminant features were detected using the Boruta R package (Kursa \& Rudnicki 2010).

Differences in chemical diversity between metabolomes were analysed using three complementary approaches. First, metabolomes were compared based on their chemical richness (i.e., the number of metabolites detected in a given soil solution). Differences between groups (CTL, Forbs, and Grasses) were tested using a negative binomial generalized linear model. Model fit was evaluated using a likelihood ratio test (LRT). Pairwise comparisons were performed on estimated marginal means using Tukey contrasts (Lenth 2018). Second, we quantified the strength of the linear relationship between the abundance of organic chemicals (DOC concentration) and metabolite richness by calculating the Pearson's product-moment correlation coefficient. Differences in DOC concentration between CTL, Forbs, and Grasses samples were tested using a one-way ANOVA followed by pairwise comparisons of estimated marginal means using Tukey contrasts (Lenth 2018). Third, chemical diversity was analysed using the approach described by Marion et al. (2015). This method relies on constructing diversity profile plots to visualise how effective diversity $(D)$ varies with diversity order $(q)$. Diversity order is a parameter used to adjust the sensitivity of diversity metrics to unequal amount of metabolites. 
Following Marion et al. (2015), effective diversity $(D)$ of order $q$ for $k$ chemical compounds can be calculated using Equation 1, where $p_{i}$ is the relative abundance of metabolite $i$. When $q=0$, all metabolites are weighted equally, which is equivalent to metabolite richness. Using larger values of $q$ increases the weight of high concentration metabolites relative to low concentration ones. For each diversity order $q$, hierarchical partitioning was used to partition total effective chemical diversity ( $\gamma^{-}$ diversity) into two components: $\alpha$-diversity (i.e., the average effective number of metabolites in a sample) and $\beta$-diversity (i.e., the effective number of completely distinct metabolomes present within a group). Diversity components were partitioned multiplicatively $(\gamma=\alpha \beta)$. To enable comparison of groups with unequal sample sizes $(n)$, we reported standardised estimates of $\beta$-diversity (turnover; see Equation 2). The proportional turnover ( $T$ ) is a scalar ranging from zero (samples are identical) to one (samples are completely different). Uncertainty around diversity estimates was approximated by hierarchical bootstrapping. Diversity partitioning was performed using the $\mathrm{R}$ package hierDiversity (Marion, Fordyce \& Fitzpatrick 2015a).

$$
\begin{array}{ll}
\left\{\begin{array}{c}
{ }^{q} D=\left(\sum_{i=1}^{k} p_{i}^{q}\right)^{1 /(1-q)} \\
{ }^{1} D=\exp \left(-\sum_{i=1}^{k} p_{i} \log p_{i}\right)
\end{array}\right. & \text { Equation 1 } \\
{ }^{q} T=\frac{q_{\beta-1}}{n-1}=\frac{1}{n-1}\left(\frac{{ }^{q} \gamma}{q_{\alpha}}-1\right) & \text { Equation 2 }
\end{array}
$$

Phase 2: Testing the impact of soil chemical legacies on the growth, biomass allocation, and functional traits of late arriving plant individuals

We set up an experiment using a full factorial and randomized design to test the impact of the metabolome found in the three soil solutions collected in phase 1 (CTL, Forbs, Grasses) on the biomass production and allocation as well as on leaf and root functional traits of two grassland species: Dianthus deltoides and Festuca rubra (Fig. 1). These two species were selected because they are common dry acidic grassland species with contrasted functional trait values. Compared to $F$. rubra, $D$. deltoides has a greater specific leaf area and $\mathrm{N}$ content, but a lower leaf dry matter content, $\mathrm{C}: \mathrm{N}$ ratio, and root tissue density (Fig. S2). Each treatment combination ( 2 species $\times 3$ soil solutions) was replicated 10 times. Sixty-two pots (volume: $2 \mathrm{l}$ ) were filled with $2 \mathrm{~kg}$ of sand. Before adding the substrate, a layer of $1 \mathrm{~cm}$ diameter glass beads was added at the bottom of the pots. In addition, a perforated plastic bag was 
placed inside each pot to facilitate root extraction at harvest. Pots were then randomly positioned in plastic trays inside a growth chamber (light phase: $21.6 \pm 1.1^{\circ} \mathrm{C}$; dark phase: $17.2 \pm 1.0^{\circ} \mathrm{C}$; $16 \mathrm{~h} \mathrm{light/8 \textrm {h }}$ dark; lamps: SANlight P4-serie, 400-760 nm; PAR: $302 \pm 21 \mu \mathrm{mol} \mathrm{m}^{-2} \mathrm{~s}^{-1}$ ). Plastic trays were randomized regularly inside the growth chamber. All pots located inside the same tray were treated with the same soil solution. The day before sowing, each pot received $100 \mathrm{ml}$ of tap water and $50 \mathrm{ml}$ of the corresponding soil solution. On the next day, half of the pots were sown with 4 seeds of $D$. deltoides and the other half with 4 seeds of $F$. rubra. After sowing, a thin layer of $5 \mathrm{~mm}$-sieved peat was added at the top of the soil and all pots received $45 \mathrm{ml}$ of soil solution. One week after sowing, excess seedlings were removed in order to keep one plant per pot. For each species, one randomly selected pot was permanently equipped with a soil moisture sensor $\left(\mathrm{ECH}_{2} \mathrm{O}\right.$ EC-5; Meter Environment, München, Germany). During the experiment, a volume of soil solution was added to each pot three times a week. The volume of soil solution added to the pots was increased by $10 \mathrm{ml}$ every two weeks (from $25 \mathrm{ml} / \mathrm{pot}$ to $55 \mathrm{ml} /$ pot, see Fig. 1). Over the entire duration of the experiment, each pot received $950 \mathrm{ml}$ of the corresponding soil solution. Plants were harvested 50 days after sowing.

\section{Plant measurements}

At harvest, leaf chlorophyll concentration was measured using a chlorophyll content meter (CCM-300; Opti-Sciences, Hudson, USA). For D. deltoides, we registered the average of 6 values measured on 6 different leaves. For F. rubra, we registered the average of 9 values measured on 3 different leaves from 3 randomly selected tillers. On each plant, 10 young, healthy, and fully expanded leaves were sampled for leaf trait measurements. The leaves were scanned on a flatbed scanner (Epson Perfection Photo V800, 24-bit colour images) at a resolution of 800 dpi. The total leaf area in each image was calculated using an ImageJ macro relying on k-means clustering for image segmentation. After scanning, the fresh weight of the 10 selected leaves was recorded. The total shoot fresh weight of each plant was measured after cutting the plants at ground level. Leaf and shoot samples were then dried at $60^{\circ} \mathrm{C}$ for $48 \mathrm{~h}$ for dry weight determination. These data were used to calculate the following traits: dry weight of a leaf, area of a leaf, specific leaf area (SLA, leaf area divided by leaf dry weight), and leaf dry matter content (LDMC, leaf dry weight divided by leaf fresh weight).

At the end of the experiment, each root system was extracted from the soil under running water and stored at $-20^{\circ} \mathrm{C}$. Root systems were washed carefully following Delory et al. (2018). For each plant, a 
representative subsample of fine roots was then spread in a transparent plastic tray filled with a thin layer of distilled water and scanned at a resolution of 1200 dpi using a flatbed scanner (Epson Perfection V800 Photo, 8-bit grayscale images). When spreading the roots inside the tray, care was taken to minimize overlapping. The root length density inside the tray averaged $0.73 \pm 0.09 \mathrm{~cm} \mathrm{~cm}^{-2}$, which is in agreement with recommendations for root length measurements using image analysis (Delory et al. 2017). In total, five to six images were acquired for each root system, which represents $1581 \pm 182 \mathrm{~cm}$ of fine roots per plant. Scanned and non-scanned roots were stored separately and dried in an oven $\left(60^{\circ} \mathrm{C}\right.$ for $\left.48 \mathrm{~h}\right)$ for dry weight determination. Root images were batch-processed with RhizoVision Explorer (Seethepalli \& York 2020) with the following settings: image thresholding level set to 215; filter particles larger than 500 pixels; root pruning threshold set to $10 ; 11$ diameter classes: from 0 to $1 \mathrm{~mm}$ by $0.1 \mathrm{~mm}$ and one extra class for roots with a diameter greater than $1 \mathrm{~mm}$. Using root parameters calculated for each diameter class (Rose 2017; Rose \& Lobet 2019), the following root traits were determined for each plant: specific root length (SRL, total root length divided by root dry weight), specific root area (SRA, total root area divided by root dry weight), root tissue density (RTD, root dry weight divided by total root volume), and length-weighted average diameter (D). The root surface density (RSD) inside the pots was used as a proxy for soil exploration and was estimated as $(R D W \times S R A) / V_{S}$, where $R D W$ and $V_{s}$ are the dry weight of the root system and the volume of soil inside a pot, respectively.

Biomass allocation was assessed by calculating the root and shoot mass fractions (i.e., the ratio between root or shoot biomass and total plant biomass). In addition, the carbon $(\mathrm{C})$ and nitrogen $(\mathrm{N})$ content of leaf and root samples was measured using a $\mathrm{C} / \mathrm{N}$ analyser (Vario EL Cube; Elementar, Langenselbold, Germany). For each plant, the $\mathrm{N}$ mass found in shoots and roots was used as a proxy for total $\mathrm{N}$ uptake. Shoot $\mathrm{N}$ content was measured with a $\mathrm{C} / \mathrm{N}$ analyser for $D$. deltoides, but was estimated based on leaf $\mathrm{N}$ concentration values for $F$. rubra.

\section{Data analysis}

When analysing and interpreting the data presented in this paper, we considered recent calls to stop using $P$-values in a dichotomous way and stop declarations of "statistical significance" in scientific papers (Amrhein, Greenland \& McShane 2019; Wasserstein, Schirm \& Lazar 2019; Rillig et al. 2019). To do so, we reported effect sizes (as measured by the absolute difference between treatment means) 
and their $95 \%$ confidence intervals computed by bootstrap resampling (10,000 iterations). Following Amrhein et al. (2019), 95\% confidence intervals will be referred to as compatibility intervals. For each response variable, effect sizes were assessed by comparing the mean values and their compatibility intervals.

To understand how soil chemical legacies of each plant community (either forbs or grasses) affected root foraging (RSD) and total $\mathrm{N}$ uptake by $D$. deltoides and F. rubra, we constructed a piecewise structural equation model (SEM) that we fitted to our data using the piecewiseSEM $R$ package (Lefcheck 2016). In our model, soil chemical legacies can affect root foraging via two mechanistic pathways: a root growth-dependent pathway and a root trait-dependent pathway. In the root growthdependent pathway, root foraging changes because of a modification in root biomass production (RDW). In the root trait-dependent pathway, root foraging changes because of a modification in specific root area (SRA). Changes in SRA can arise from changes in root diameter (D) and/or specific root length (SRL). These two pathways are not mutually exclusive as an overall change in root foraging can occur via simultaneous changes in morphological root traits and root biomass production. How changes in root foraging affected total $\mathrm{N}$ uptake was also evaluated in the model. Mechanisms not captured by the root growth-dependent and root trait-dependent pathways are represented by a direct path between soil chemical legacy and $\mathrm{N}$ uptake. The goodness-of-fit of each model was assessed using Fisher's $C$ test statistic (Lefcheck 2016).

Data analysis was performed in R 3.6.3 (R Core Team 2020). Plots were created using ggplot2 (Wickham 2016) and ggpubr (Kassambara 2020).

\section{Results}

Plant community composition affects the chemical composition and diversity of the metabolome found in the soil solution

A principal component analysis showed a good separation between the metabolomes of soil solutions collected from Forbs, Grasses, and CTL mesocosms (Fig. 2a, Fig. S3). For each soil solution category, the abundance of the 20 most discriminant metabolites is provided in Fig. S5. A total of 38 (32 pos/6 neg), 38 (35 pos/3 neg), and 81 (59 pos/22 neg) metabolites were only detected in CTL, Forbs, and Grasses samples, respectively. The richness of metabolites found in the soil solution depended on the composition of plant communities (Fig. $2 b$; $L R T=7.2, P=0.03$ ). When plants were present, the soil 
solution contained more metabolites than when plants were absent, but this difference was stronger for forb communities than for grass communities. On average, the metabolome found in the soil solution of forb and grass communities contained 88 and 52 metabolites more than CTL samples, respectively. Compared to tap water, the soil solution of CTL mesocosms contained an average of 655 more metabolites.

DOC concentration was highest in the soil solution of forb communities (Fig. 2c; $F_{2,26=9.8} P=0.0007$ ). In comparison with CTL samples, Forbs and Grasses samples had 25\% and $3 \%$ more DOC, respectively. We found a strong positive relationship between the total abundance of organic chemicals in the soil solution and metabolite richness (Fig. $2 \mathrm{c} ; \mathrm{r}=0.65, P=0.0001$ ), thus showing that samples with high DOC concentration also had a high metabolite richness. This is consistent with the abundancedependence of chemical diversity that has been observed across multiple levels of biological organisation (Wetzel \& Whitehead 2020).

We used diversity profile plots to visualise the relationship between effective chemical diversity and diversity order $(q)$ for each treatment group. When more weight was given to abundant metabolites (i.e., for larger values of $q$ ), we observed a strong decrease in $\alpha$ - and $\gamma$-diversity (Fig. $2 d, e)$. This indicates that chemical profiles contained a few compounds of high abundance and many compounds of low abundance (unevenness). At the highest diversity order used in this study ( $q=3)$, the effective number of metabolites was on average equal to 30 for Grasses, 38 for CTL, and 41 for Forbs. Although $\beta$ diversity - as measured by the proportional turnover among replicates - was similar between groups when diversity order was close to zero (CTL: 0.133 , Forbs: 0.116 , and Grasses: 0.120 ), differences became stronger when abundant metabolites were weighted more heavily ( $q=3$ ) (Fig. 2f). In this case, $\beta$-diversity was between four and five times smaller in Grasses than in Forbs and CTL, respectively. This result highlights the fact that replicates of soil solution samples collected from grass communities were more similar in terms of composition of abundant metabolites than the replicates of samples collected from forb communities and CTL mesocosms. 

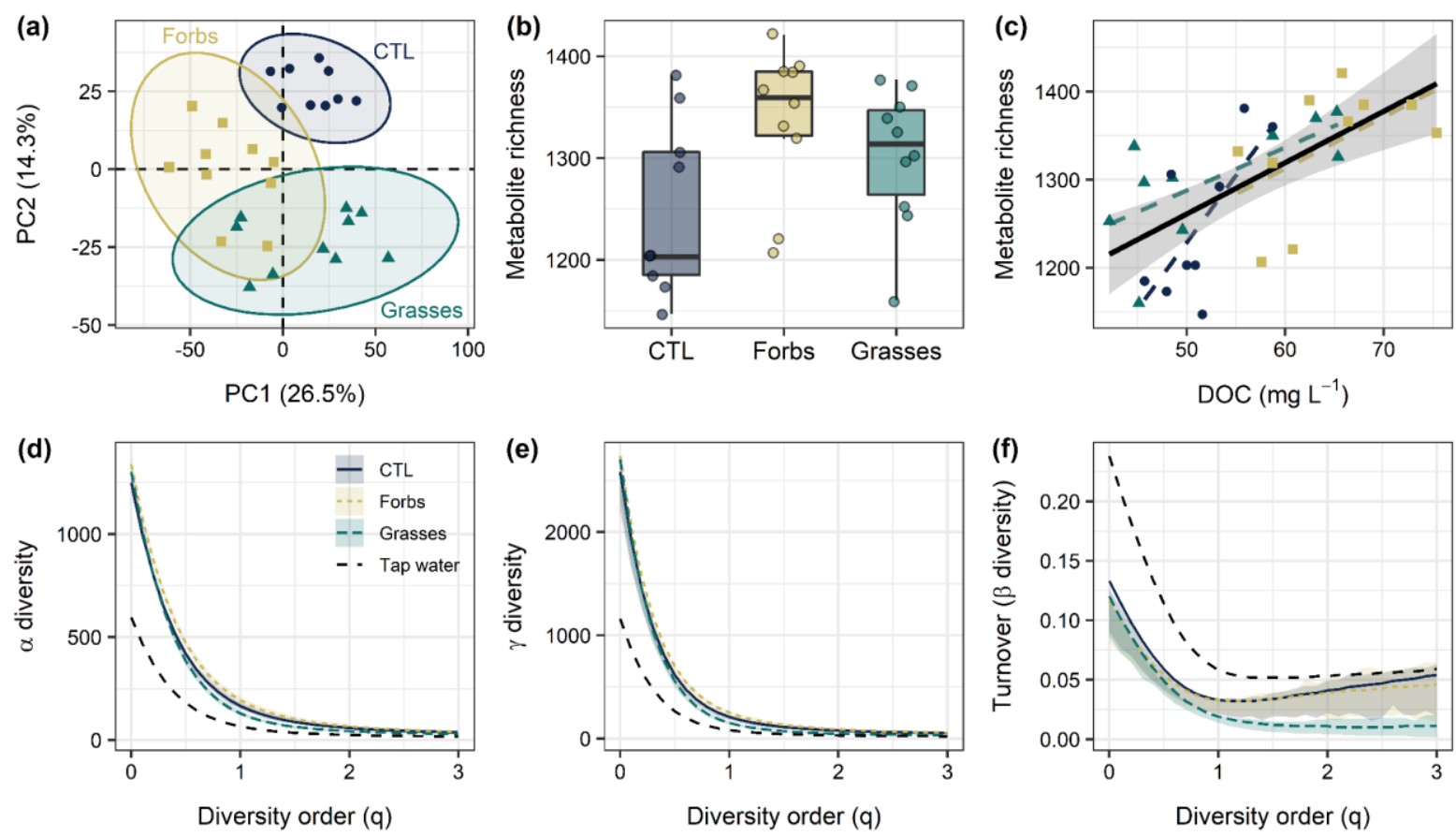

Fig. 2 Plant community composition affects the chemical composition and diversity of the metabolome found in the soil solution. (a) Principal component analysis performed on a dataset containing both positive and negative ionisation data. (b) Differences in metabolite richness between soil solution samples collected from CTL (controls, soil only), Forbs, and Grasses mesocosms (see Fig. 1). (c) Positive chemical diversity - abundance relationship. (d-f) Chemical diversity profile plots showing the decrease in effective $\alpha$-diversity (d), $\gamma$-diversity (e), and $\beta$-diversity (f) with increasing diversity order. Panels b-f rely solely on positive ionisation data (results from negative ionisation data are provided in Fig. S4). In panel $f$, turnover is a standardised estimate of $\beta$-diversity ranging from zero (samples are identical) to one (samples are completely different). In panels a-c, each dot is an individual observation ( $n=9$ for CTL and $n=10$ for Forbs and Grasses).

\section{Soil chemical legacies modulate root foraging in Dianthus deltoides, but not in Festuca rubra}

The two species investigated in this study responded differently to the metabolome found in the soil solutions of forb and grass communities. While $F$. rubra did not show any difference between treatments for all variables measured in this study (Fig. 3-6), D. deltoides' response depended on whether the soil solution came from a forb or a grass community.

Compared to plants treated with the soil solution collected from CTL mesocosms $(\mathrm{CTL}), D$. deltoides individuals treated with the metabolome found in the soil solution of a forb community had a lower root productivity (-26\%, Fig. 3b), but unchanged shoot productivity (Fig. 3a). This led to a greater shoot mass fraction (+5\%, Fig. 3c) and a lower root mass fraction (-18\%, Fig. 3d) in D. deltoides plants treated with the soil solution of a forb community. This soil chemical legacy effect on biomass production and allocation, however, was not observed when $D$. deltoides was treated with the soil solution of a grass community (Fig. 3a-d). 

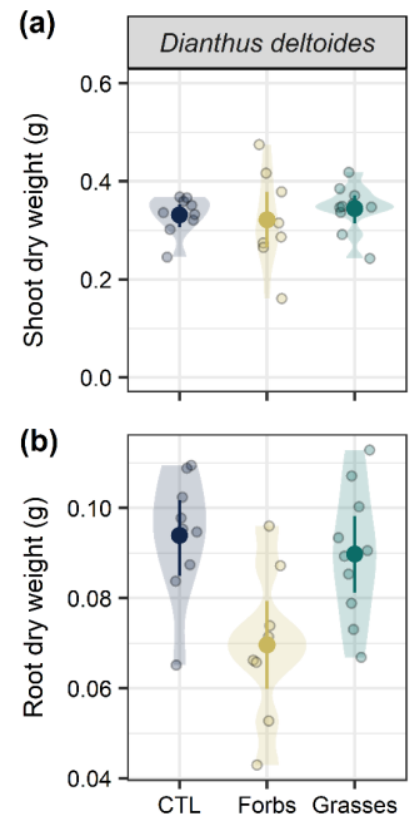
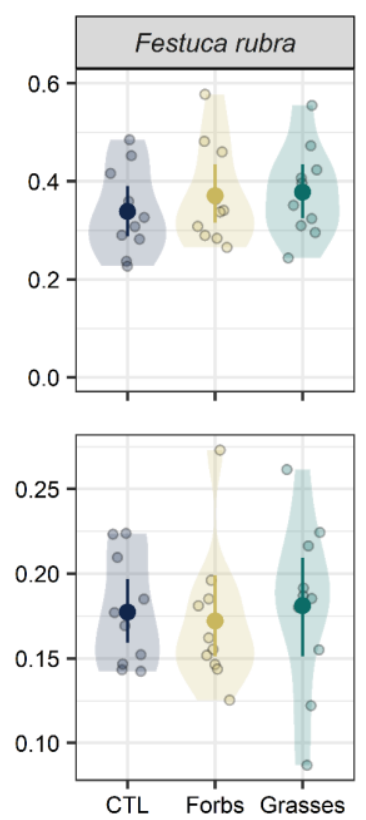
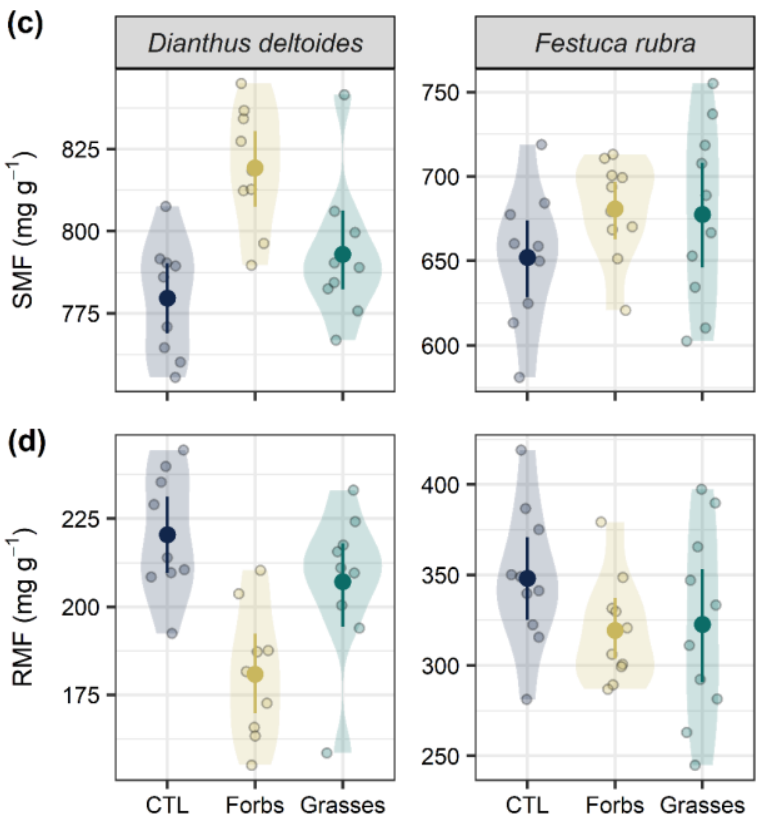

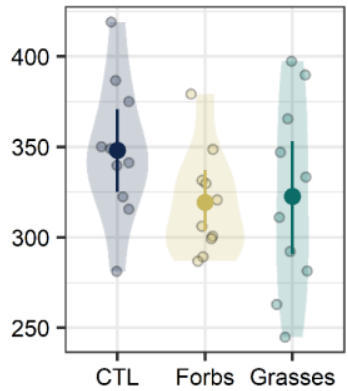

Fig. 3 Biomass production (a, b) and allocation (c, d) of $D$. deltoides and $F$. rubra when exposed to the metabolome found in the soil solution of plant communities differing in species composition. Soil solution was collected from mesocosms in which a forb (Forbs) or a grass (Grasses) community was sown, as well as from unsown mesocosms containing only soil (CTL). For each treatment, mean values and compatibility intervals are shown $(n=9-10)$. Individual observations and data distributions are displayed at the back of each graph as dots and density plots, respectively. SMF, shoot mass fraction; RMF, root mass fraction. For each response variable, effect sizes and compatibility intervals can be found in Fig. S6.

While none of the leaf traits measured on $D$. deltoides were affected by the composition of the metabolome found in the different soil solutions (Fig. 4), it had a strong impact on root foraging (Fig. 5a) and root morphology (Fig. 5b-c). In comparison with CTL plants, D. deltoides individuals treated with the soil solution of a grass community had a lower SRL (-13\%) and a lower SRA (-13\%). This effect on SRL and SRA was paralleled by a slight increase in RTD (+8\%, Fig. $5 d)$, but an effect size of zero (i.e., no increase in RTD) was also compatible with our data. We did not observe any effect of our treatments on root diameter (Fig. 5e) or chemical root traits (Fig. 5f-h). The SRL, SRA, and RTD values of $D$. deltoides individuals that were treated with the soil solution of a forb community were intermediate between the values measured on CTL plants and the values measured on plants treated with the metabolome found in the soil solution of a grass community (Fig. $5 b-d)$.

Overall, root foraging - as measured by RSD - decreased when $D$. deltoides was treated with the soil solution of a forb or a grass community (Fig. 5a). This decrease in root foraging was stronger when plants were treated with the soil solution from a forb community (-33\%) than when plants received the soil solution from a grass community $(-16 \%)$. Structural equation modelling showed that the mechanism 

perpetuity. It is made available under aCC-BY 4.0 International license.

behind decreased root foraging by $D$. deltoides was dependent on the composition of the metabolome found in the soil solutions (Fig. 6). When soil chemical legacies were created by a forb community, decreased root foraging was mainly due to a decrease in root biomass production (root growthdependent path, Fig. 6a). When soil chemical legacies were created by a grass community, however, the mechanism explaining the observed reduction in root foraging was a reduction in SRA following a decrease in SRL (root trait-dependent path, Fig. 6b). Although root foraging decreased when the soil solution of a forb or a grass community was applied to $D$. deltoides, this was not paralleled by a decrease in total $\mathrm{N}$ uptake (Fig. 6a,b). 
bioRxiv preprint doi: https://doi.org/10.1101/2020.09.01.276840; this version posted October 16, 2020. The copyright holder for this preprint (which was not certified by peer review) is the author/funder, who has granted bioRxiv a license to display the preprint in perpetuity. It is made available under aCC-BY 4.0 International license.
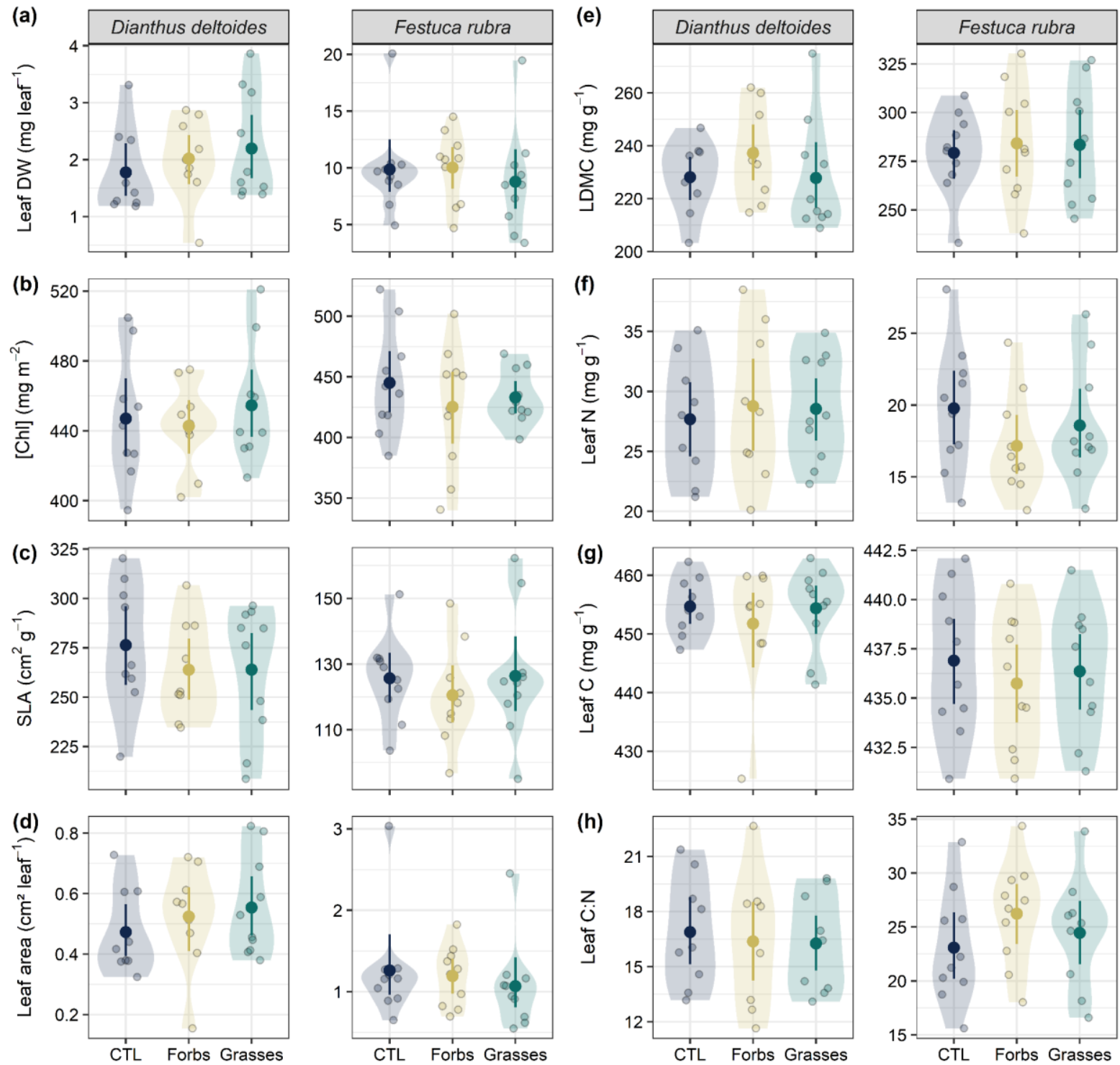

Fig. 4 Leaf functional traits of $D$. deltoides and $F$. rubra when exposed to the metabolome found in the soil solution of plant communities differing in species composition. Soil solution was collected from mesocosms in which a forb (Forbs) or a grass (Grasses) community was sown, as well as from unsown mesocosms containing only soil (CTL). The following leaf traits were measured: (a) dry weight (DW) of a leaf, (b) leaf chlorophyll concentration ([Chl]), (c) specific leaf area (SLA), (d) area of a leaf, (e) leaf dry matter content (LDMC), (f) leaf $\mathrm{N}$ concentration, (g) leaf $\mathrm{C}$ concentration, and (h) leaf C:N ratio. For each treatment, mean values and compatibility intervals are shown ( $n=9-10)$. Individual observations and data distributions are displayed at the back of each graph as dots and density plots, respectively. For each response variable, effect sizes and compatibility intervals can be found in Fig. S7. 
bioRxiv preprint doi: https://doi.org/10.1101/2020.09.01 276840; this version posted October 16,2020 . The copyright holder for this preprint (which was not certified by peer review) is the author/funder, who has granted bioRxiv a license to display the preprint in perpetuity. It is made available under aCC-BY 4.0 International license.
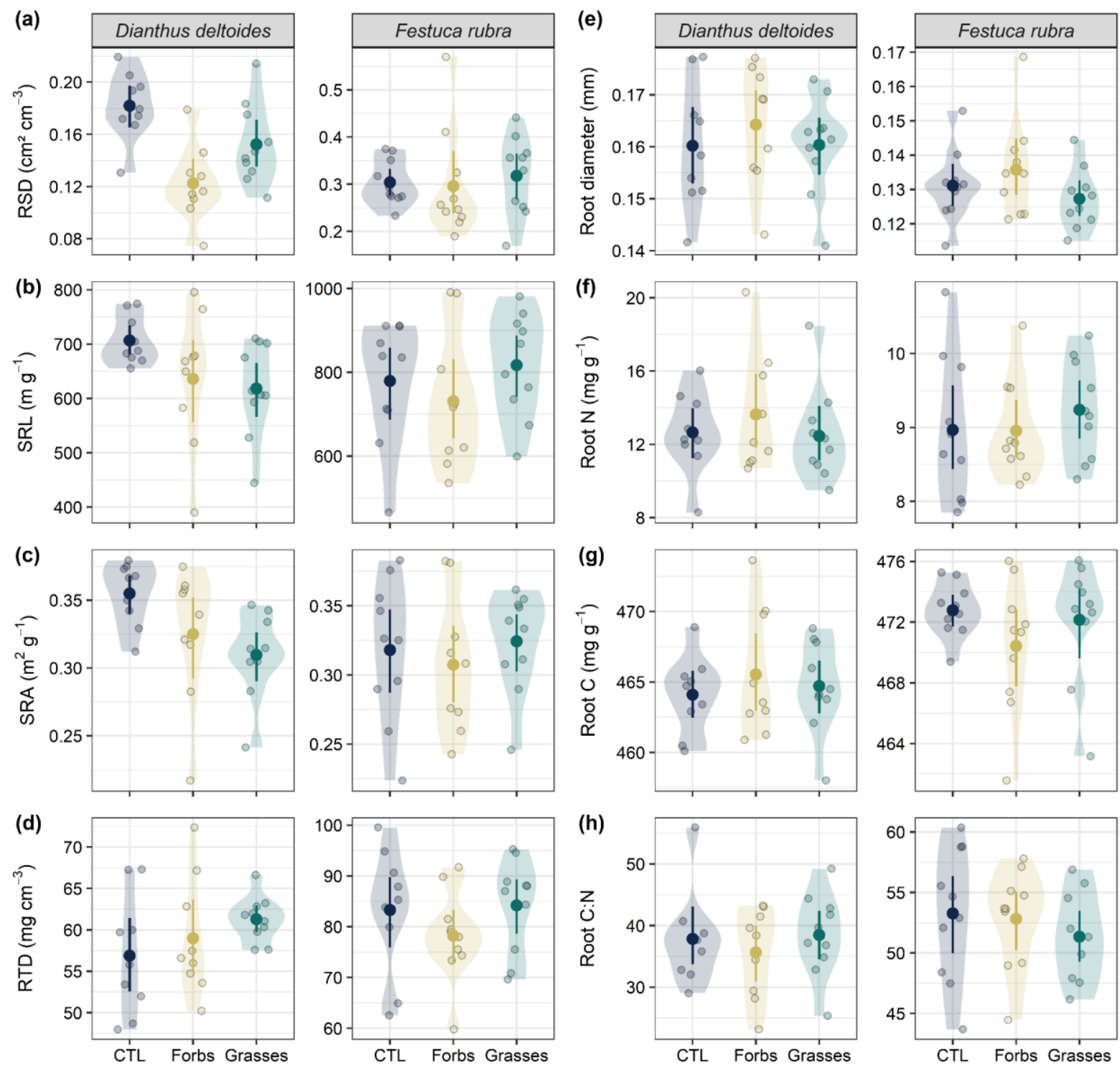

Fig. 5 Root functional traits of $D$. deltoides and F. rubra when exposed to the metabolome found in the soil solution of plant communities differing in species composition. Soil solution was collected from mesocosms in which a forb (Forbs) or a grass (Grasses) community was sown, as well as from unsown mesocosms containing only soil (CTL). The following root traits were measured: (a) root surface density (RSD), (b) specific root length (SRL), (c) specific root area (SRA), (d) root tissue density (RTD), (e) root diameter, (f) root $\mathrm{N}$ concentration, (g) root $\mathrm{C}$ concentration, and (h) root $\mathrm{C}: \mathrm{N}$ ratio. For each treatment, mean values and compatibility intervals are shown $(n=9-10)$. Individual observations and data distributions are displayed at the back of each graph as dots and density plots, respectively. For each response variable, effect sizes and compatibility intervals can be found in Fig. S8. 


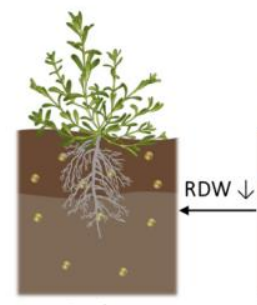

Forbs

(a)

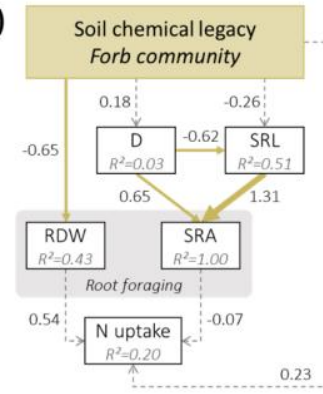

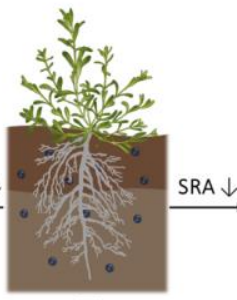

CTL (b)

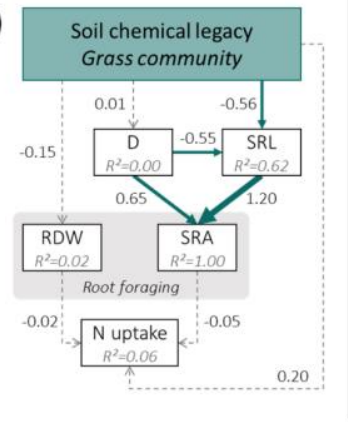

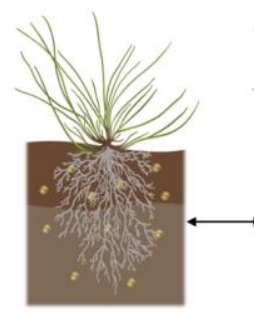

Forbs

(c)

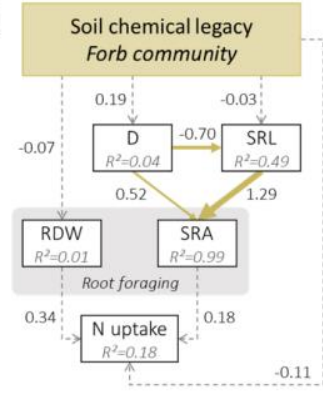

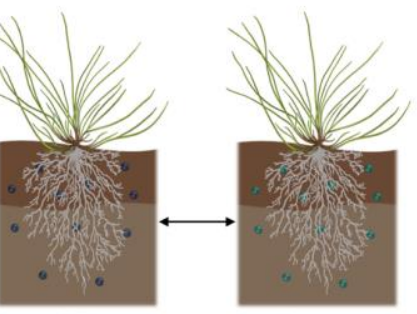

Grasses

(d)

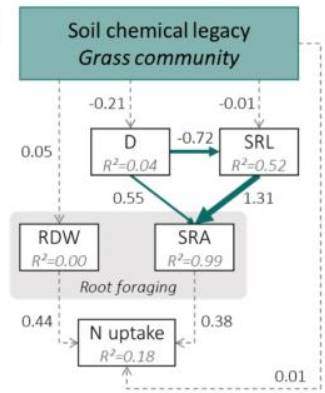

Fig. 6 Soil chemical legacies modulate root foraging in $D$. deltoides (a, b), but not in $F$. rubra (c, d). Reduced root foraging by $D$. deltoides arose via two different mechanistic pathways depending on the composition of the soil solution's metabolome: a root growth-dependent pathway (Forbs) and a root trait-dependent pathway (Grasses). For paths with $\mathrm{P}<0.05$, the thickness of each arrow (either yellow or green) was scaled based on the magnitude of the standardized regression coefficient displayed next to it. Paths with $P \geq 0.05$ are represented by dashed grey arrows. (a) D. deltoides (CTL vs Forbs): Fisher's $C=17.9, \mathrm{df}=12, P=0.12$; (b) $D$. deltoides (CTL vs Grasses): Fisher's $C=7.4, \mathrm{df}=12$, $P=0.83$; (c) F. rubra (CTL vs Forbs): Fisher's $C=10.6, \mathrm{df}=12, P=0.57$; (d) $F$. rubra (CTL vs Grasses): Fisher's $C=17.7, \mathrm{df}=12, P=0.13$. $\mathrm{D}$, root diameter; $\mathrm{SRL}$, specific root length; SRA, specific root area; $\mathrm{RDW}$, root dry weight; $\mathrm{N}$ uptake, total plant $\mathrm{N}$ uptake.

\section{Discussion}

In this study, we demonstrated that soil chemical legacies can play an important role for the creation of belowground priority effects by affecting root responses in later arriving plant individuals. Although $F$. rubra was largely unaffected by soil chemical legacies, we found that root foraging by $D$. deltoides decreased when it was exposed to the metabolome found in the soil solution of a forb or a grass community. This reduction in root foraging by $D$. deltoides arose via two different mechanistic pathways depending on whether soil chemical legacies were created by a forb or a grass community. When $D$. deltoides was treated with the soil solution of a forb community, root foraging decreased because of a decrease in root productivity (root growth-dependent pathway). When $D$. deltoides was treated with the soil solution of a grass community, however, root foraging decreased because of a decrease in SRA (root trait-dependent pathway). These results support the fact that priority effects in plant communities are not only a matter of competition for shared resources, but may also result from niche modification by early-arriving species (i.e., modification of the metabolome found in the soil solution). 
bioRxiv preprint doi: https://doi.org/10.1101/2020.09.01 276840; this version posted October 16, 2020. The copyright holder for this preprint (which was not certified by peer review) is the author/funder, who has granted bioRxiv a license to display the preprint in perpetuity. It is made available under aCC-BY 4.0 International license.

Since the composition of root exudates and soil microorganisms is strongly influenced by plant species identity (Bever 2003; Leff et al. 2018; Mommer et al. 2018; Oburger \& Jones 2018), it is therefore not surprising that the composition and chemical diversity of the metabolomes found in the solutions of forb and grass communities differed in our study. Compared to CTL soil solution, the metabolome found in the soil solution of forb communities was characterized by a greater chemical richness and a greater DOC concentration. When more weight was given to abundant metabolites, samples from grass communities were characterised by the lowest chemical richness ( $\alpha$-diversity) and the lowest turnover between samples ( $\beta$-diversity). Altogether, these results confirm that the identity of early-arriving species has a strong impact on the chemical composition of the soil solution's metabolome. Although our metabolomics data apply to plant communities and not isolated plant individuals, our results are consistent with previous studies showing that the rate of $\mathrm{C}$ exudation by plant roots (de Vries et al. 2019; Sun et al. 2020) as well as the chemical composition and diversity of root exudates (Herz et al. 2018; Dietz et al. 2019) strongly depend on species identity.

The two focal species investigated in this study $-D$. deltoides and $F$. rubra - responded differently when treated with the soil solution of a grass or a forb community. While root foraging of single $D$. deltoides individuals dropped when plants were exposed to soil chemical legacies created by forb or grass communities, none of the variables measured on F. rubra were affected. Such species-specificity is consistent with results from other experiments showing that neighbour presence and identity can both alter root foraging in a species-specific and context-dependent manner (Mahall \& Callaway 1991; Semchenko, John \& Hutchings 2007b; Mommer, van Ruijven, Jansen, van de Steeg \& de Kroon 2012; Padilla et al. 2013). PSF experiments have also provided strong support for species-specific root responses to soil legacies (Callaway \& Ridenour 2004; van der Putten et al. 2013; Ristok et al. 2019). Both the direction and magnitude of PSF effects have been shown to vary between individual species (Kardol et al. 2007; Hendriks et al. 2013, 2015a), but also between early- and late-successional species (Kardol, Martijn Bezemer \& Van Der Putten 2006). Using a large pool of grassland species, Cortois et al. (2016) showed that the strength of PSF effects varied between plant functional groups and was related to morphological and biotic root traits. They showed that plants with acquisitive trait values suffered from more negative PSF effects than plants with conservative trait values (Cortois et al. 2016). Interestingly, we found a similar pattern in our study: the species with the most acquisitive trait values (D. deltoides) was the only one affected by soil chemical legacies. 
bioRxiv preprint doi: https://doi.org/10.1101/2020.09.01 276840; this version posted October 16, 2020. The copyright holder for this preprint (which was not certified by peer review) is the author/funder, who has granted bioRxiv a license to display the preprint in perpetuity. It is made available under aCC-BY 4.0 International license.

The fact that none of the variables measured in our study on $F$. rubra differed between treatments is consistent with previous studies showing that this species produced a similar amount of root biomass and did not change its root distribution when growing in monocultures or in mixtures (Mommer et al. 2010). In addition, root biomass production and $\mathrm{N}$ uptake values of $F$. rubra grown in soil conditioned by conspecifics were either lower (Hendriks et al. 2015b a) or not different (in 't Zandt et al. 2020) from the values measured on individuals grown in soil conditioned by heterospecifics. Altogether, these results suggest that root responses of $F$. rubra seem to be little affected by the identity of neighbours growing next to it or by soil legacy effects. On the contrary, our results showed that $D$. deltoides individuals strongly responded to soil chemical legacies of different plant communities. Despite its lower root productivity, $D$. deltoides was able to take up as much $\mathrm{N}$ as $F$. rubra, which shows that $D$. deltoides had a greater competitive ability in our experiment.

Although it has been shown that more $\mathrm{C}$ is exuded by metabolically active roots with high $\mathrm{N}$ content and high respiration rate (Sun et al. 2020), we do not yet know whether differences in plant economics between the two focal species used in our experiment can explain plant species' responses to soil chemical legacies. Here, we argue that functional trait-based approaches similar to the ones used to improve the predictability of PSF effects hold much potential to better understand how and when plant species are more likely to respond to soil chemical cues (Baxendale, Orwin, Poly, Pommier \& Bardgett 2014; Kardol, Veen, Teste \& Perring 2015; Cortois et al. 2016). For instance, based on the results of our study, it could be hypothesised that plant species located on the "fast" side of the resource conservation gradient would be more likely to respond to soil chemical cues than species located on the "slow" side of the gradient. This hypothesis is based on the assumption that soil foraging by fastgrowing species with metabolically active but short-lived roots would benefit more from soil chemical cues allowing a fast and reliable identification of the identity and competitive ability of neighbours than slow-growing species. More research is needed to test this hypothesis across a wide range of plant species.

Our results showed that the mechanism leading to reduced soil exploration by $D$. deltoides was contextdependent. Depending on whether plants were treated with the soil solution of a forb or a grass community, the observed decrease in root foraging was caused by a reduction in root biomass production or a reduction in SRA, respectively. Interestingly, none of these root responses negatively affected total $\mathrm{N}$ uptake, which suggests that plastic root responses such as increased $\mathrm{N}$ uptake rates 
bioRxiv preprint doi: https://doi.org/10.1101/2020.09.01 276840; this version posted October 16, 2020. The copyright holder for this preprint (which was not certified by peer review) is the author/funder, who has granted bioRxiv a license to display the preprint in perpetuity. It is made available under aCC-BY 4.0 International license.

might have played a role (Hendriks et al. 2015b; Freschet, Violle, Bourget, Scherer-Lorenzen \& Fort 2018). Our results support the idea that chemicals present in the soil solution can carry information about species composition. This adds up to the growing body of evidence showing that soil chemical legacies can trigger context-dependent responses affecting morphological root traits and soil exploration (Semchenko et al. 2014), which might be an important mechanism creating belowground priority effects in both nutrient-rich (Semchenko et al. 2014; Weidlich et al. 2018) and nutrient-poor systems.

Overall, root foraging was more strongly reduced when $D$. deltoides was treated with the soil solution of a forb community, which supports our hypothesis that late-arriving species would be more affected by soil chemical legacies created by a plant community composed of functionally similar species. The decrease in root biomass production and root mass fraction observed when $D$. deltoides was treated with the soil solution of a forb community could be a plant's response aiming to lower the intensity of competition between functionally similar species. This hypothesis, however, is not strongly supported by our data because the observed decrease in root biomass production and allocation was not paralleled by a reduction in total $\mathrm{N}$ uptake (Fig. 6a), which would be expected if the relationship between root foraging and $\mathrm{N}$ uptake is positive (Mommer et al. 2011). However, we cannot exclude that the lower root productivity of $D$. deltoides may have affected the uptake of other soil resources not measured in our study. Alternatively, the observed reduction in root productivity could also be a consequence of the presence of allelochemicals inhibiting root growth in the soil solution of forb communities (Semchenko, Hutchings \& John 2007a).

When $D$. deltoides was treated with the soil solution of a grass community, the observed decrease in RSD was solely due to changes in root morphology. In this situation, the lower root foraging capacity of D. deltoides was explained by a decrease in SRL leading to a reduction in SRA. This decrease in SRL was only weakly associated with an increase in RTD, which is consistent with studies reporting SRL and RTD to be related to two orthogonal axes of variation in the root economics space (Kramer-Walter et al. 2016; Bergmann et al. 2020). Root foraging by $D$. deltoides was the least affected when it was treated with the soil solution of a grass community. This observation is consistent with previous studies showing that forbs tend to grow better with grasses than with other forbs (Cahill, Kembel, Lamb \& Keddy 2008), or that forbs grow better with heterospecifics than conspecifics (Semchenko, Abakumova, Lepik \& Zobel 2013). This is also consistent with PSF experiments showing that forbs grow better on soil 
bioRxiv preprint doi: https://doi.org/10.1101/2020.09.01 276840; this version posted October 16, 2020. The copyright holder for this preprint (which was not certified by peer review) is the author/funder, who has granted bioRxiv a license to display the preprint in perpetuity. It is made available under aCC-BY 4.0 International license.

conditioned by grasses than on soil conditioned by other forbs (Hendriks et al. 2013; Heinen et al. 2020). Based on recent evidence suggesting that root trait displacement enhances local species coexistence (Valverde-Barrantes, Smemo, Feinstein, Kershner \& Blackwood 2013) and that plants with lower SRL are better at tolerating interspecific competition (Semchenko, Lepik, Abakumova \& Zobel 2018) and may be better able to cope with nitrogen stress (Freschet et al. 2018), we hypothesise that the production of roots with a lower SRL by $D$. deltoides is probably a plastic response that may increase plant fitness in the presence of grass competitors.

The results presented in this study pave the way for further research aimed at providing a more detailed understanding of the biological mechanisms underlying individual plant responses to soil chemical cues, as well as the ecological consequences of these interactions on plant communities. In particular, we argue that more research is needed to elucidate the origin and identity of the metabolites driving the growth and trait responses in later arrivers. Although methodologically challenging (Peters et al. 2018; Uthe et al. 2021), the identification of key metabolites would be an important first step for the realisation of bioassays designed to unravel the molecular mechanisms of root-root interactions. In addition, studies investigating the relationship between phytochemical diversity/abundance in the rhizosphere and priority effect strength are needed to improve our capacity to predict how plant order of arrival affects species coexistence. Lastly, our experimental design did not allow us to take the spatiotemporal dynamics of the metabolome found in the soil solution of plant communities into account. Considering that the quality and quantity of metabolites found in the rhizosphere vary in space and time (Perry et al. 2007; Oburger \& Jones 2018; de Vries et al. 2019), experiments considering these spatiotemporal dynamics would offer unique opportunities to shed light on chemically-mediated plant-plant interactions occurring in the soil.

To conclude, our work shows that the composition and chemical diversity of the soil solution's metabolome depend on the species composition of plant communities. In addition, it reveals that soil chemical legacies can cause belowground priority effects in some grassland species by affecting root foraging of later arriving plants. Importantly, the soil chemical legacy effects observed in our study were dependent on the composition of the soil solution's metabolome since it affected the biological mechanism responsible for altered root foraging in later arriving plants (i.e., root foraging changed because of a modification in root traits or root biomass production). 


\section{Acknowledgements}

The authors thank Dr Thomas Niemeyer for his great technical support, as well as Lukas van Treeck, Anaiis Verstraeten, and Ksenia Cherepanova for their invaluable help in measuring root traits. This research project greatly benefited from the online course "Image analysis methods for biologists" taught by Tony Pridmore, Andrew French, Michael Pound and Amy Lowe (University of Nottingham, UK). The plant illustrations used in this paper were made by Carolina Levicek (www.carolinalevicek.com). The authors thank Amit Kumar and Inés Alonso-Crespo for their constructive comments on the manuscript. For this project, Delory BM was supported by a research start-up grant (Forschungsanschubfinanzierung) from Leuphana University Lüneburg (Germany). Nicole M. van Dam and Alexander Weinhold gratefully acknowledge the German Research Foundation for funding the German Centre for Integrative Biodiversity Research (iDiv) Halle-Jena-Leipzig (DFG- FZT 118, 202548816).

\section{Author contributions}

BMD conceived and designed the experiment; BMD, HS and SMS performed the experiment; BMD, HS, SMS, LS and VMT collected data; AW and NMvD performed the metabolomics analyses; BMD and AW processed metabolomics data; BMD analysed the data and led the writing of the manuscript. All authors contributed critically to the drafts and gave final approval for publication.

\section{Data availability statement}

The data and $\mathrm{R}$ codes that support the findings of this study are openly available in Zenodo at https://doi.org/10.5281/zenodo.4010162. 


\section{References}

Amrhein V., Greenland S. \& McShane B. (2019) Scientists rise up against statistical significance. Nature 567, 305-307.

Bardgett R.D., Mommer L. \& de Vries F.T. (2014) Going underground: root traits as drivers of ecosystem processes. Trends in Ecology and Evolution 29, 692-699.

Baxendale C., Orwin K.H., Poly F., Pommier T. \& Bardgett R.D. (2014) Are plant-soil feedback responses explained by plant traits? New Phytologist 204, 408-423.

Benton H.P., Want E.J. \& Ebbels T.M.D. (2010) Correction of mass calibration gaps in liquid chromatography-mass spectrometry metabolomics data. Bioinformatics 26, 2488-2489.

Bergmann J., Weigelt A., van der Plas F., Laughlin D.C., Kuyper T.W., Guerrero-Ramirez N., ... Mommer L. (2020) The fungal collaboration gradient dominates the root economics space in plants. Science Advances 6, eaba3756.

Bertin C., Yang X. \& Weston L.A. (2003) The role of root exudates and allelochemicals in the rhizosphere. Plant and Soil 256, 67-83.

Bever J.D. (2003) Soil community feedback and the coexistence of competitors: Conceptual frameworks and empirical tests. New Phytologist 157, 465-473.

Bever J.D., Dickie I.A., Facelli E., Facelli J.M., Klironomos J., Moora M., ... Zobel M. (2010) Rooting theories of plant community ecology in microbial interactions. Trends in Ecology \& Evolution 25, 468-478.

Biedrzycki M.L., Jilany T.A., Dudley S.A. \& Bais H.P. (2010) Root exudates mediate kin recognition in plants. Communicative \& Integrative Biology 3, 28-35.

Cahill J.F., Kembel S.W., Lamb E.G. \& Keddy P.A. (2008) Does phylogenetic relatedness influence the strength of competition among vascular plants? Perspectives in Plant Ecology, Evolution and Systematics 10, 41-50.

Callaway R.M. \& Aschehoug E.T. (2000) Invasive plants versus their new and old neighbors: a mechanism for exotic invasion. Science 290, 521-523.

Callaway R.M. \& Ridenour W.M. (2004) Novel weapons: invasive success and the evolution of increased competitive ability. Frontiers in Ecology and the Environment 2, 436-443.

Chase J.M. (2003) Community assembly: when should history matter? Oecologia 136, 489-498.

Cortois R., Schröder-Georgi T., Weigelt A., van der Putten W.H. \& De Deyn G.B. (2016) Plant-soil 
feedbacks: role of plant functional group and plant traits. Journal of Ecology 104, 1608-1617.

van Dam N.M. \& Bouwmeester H.J. (2016) Metabolomics in the rhizosphere : tapping into belowground chemical communication. Trends in Plant Science 21, 256-265.

Delory B.M., Delaplace P., Fauconnier M.-L. \& du Jardin P. (2016) Root-emitted volatile organic compounds: can they mediate belowground plant-plant interactions? Plant and Soil 402, 1-26.

Delory B.M., Weidlich E.W.A., van Duijnen R., Pagès L. \& Temperton V.M. (2018) Measuring plant root traits under controlled and field conditions: step-by-step procedures. In Root development. Methods in Molecular Biology. (eds D. Ristova \& E. Barbez), pp. 3-22. Humana Press, New York, NY.

Delory B.M., Weidlich E.W.A., von Gillhaussen P. \& Temperton V.M. (2019a) When history matters: the overlooked role of priority effects in grassland overyielding. Functional Ecology 33, 2369-2380.

Delory B.M., Weidlich E.W.A., Kunz M., Neitzel J. \& Temperton V.M. (2019b) The exotic species Senecio inaequidens pays the price for arriving late in temperate European grassland communities. Oecologia 191, 657-671.

Delory B.M., Weidlich E.W.A., Meder L., Lütje A., van Duijnen R., Weidlich R. \& Temperton V.M. (2017) Accuracy and bias of methods used for root length measurements in functional root research. Methods in Ecology and Evolution 8, 1594-1606.

Dietz S., Herz K., Döll S., Haider S., Jandt U., Bruelheide H. \& Scheel D. (2019) Semi-polar root exudates in natural grassland communities. Ecology and Evolution 9, 5526-5541.

Eisenhauer N., Lanoue A., Strecker T., Scheu S., Steinauer K., Thakur M.P. \& Mommer L. (2017) Root biomass and exudates link plant diversity with soil bacterial and fungal biomass. Scientific reports 7, 44641 .

Fargione J., Brown C.S. \& Tilman D. (2004) Community assembly and invasion: an experimental test of neutral versus niche processes. Proceedings of the National Academy of Sciences of the United States of America 101, 8916-8920.

Freschet G.T., Violle C., Bourget M.Y., Scherer-Lorenzen M. \& Fort F. (2018) Allocation, morphology, physiology, architecture: the multiple facets of plant above- and below-ground responses to resource stress. New Phytologist 219, 1338-1352.

Fukami T. (2015) Historical contingency in community assembly: integrating niches, species pools, and priority effects. Annual Review of Ecology Evolution and Systematics 46, 1-23. 
Fukami T., Dickie I.A., Paula Wilkie J., Paulus B.C., Park D., Roberts A., ... Allen R.B. (2010) Assembly history dictates ecosystem functioning: evidence from wood decomposer communities. Ecology Letters 13, 675-684.

Grman E. \& Suding K.N. (2010) Within-year soil legacies contribute to strong priority effects of exotics on native California grassland communities. Restoration Ecology 18, 664-670.

Halliday F.W., Penczykowski R.M., Barrès B., Eck J.L., Numminen E. \& Laine A.-L. (2020) Facilitative priority effects drive parasite assembly under coinfection. Nature Ecology \& Evolution, doi: 10.1038/s41559-020-01289-9.

Heinen R., Hannula S.E., Long J.R. De, Huberty M., Jongen R., Kielak A., .. Bezemer T.M. (2020) Plant community composition steers grassland vegetation via soil legacy effects. Ecology Letters 23, 973-982.

Hendriks M., Mommer L., de Caluwe H., Smit-Tiekstra A.E., van der Putten W.H. \& de Kroon H. (2013) Independent variations of plant and soil mixtures reveal soil feedback effects on plant community overyielding. Journal of Ecology 101, 287-297.

Hendriks M., Ravenek J.M., Smit-Tiekstra A.E., van der Paauw J.W., de Caluwe H., van der Putten W.H., ... Mommer L. (2015a) Spatial heterogeneity of plant-soil feedback affects root interactions and interspecific competition. New Phytologist 207, 830-840.

Hendriks M., Visser E.J.W., Visschers I.G.S., Aarts B.H.J., Caluwe H., Smit-Tiekstra A.E., .. Mommer L. (2015b) Root responses of grassland species to spatial heterogeneity of plant-soil feedback. Functional Ecology 29, 177-186.

Henneron L., Cros C., Picon-Cochard C., Rahimian V. \& Fontaine S. (2020) Plant economic strategies of grassland species control soil carbon dynamics through rhizodeposition. Journal of Ecology $108,528-545$.

Herz K., Dietz S., Gorzolka K., Haider S., Jandt U., Scheel D. \& Bruelheide H. (2018) Linking root exudates to functional plant traits. PLOS ONE 13, e0204128.

Hess M.C.M., Buisson E., Fontes H., Bacon L., Sabatier F. \& Mesléard F. (2020) Giving recipient communities a greater head start and including productive species boosts early resistance to invasion. Applied Vegetation Science 23, 340-352.

Hu L., Robert C.A.M., Cadot S., Zhang X., Ye M., Li B., ... Erb M. (2018) Root exudate metabolites drive plant-soil feedbacks on growth and defense by shaping the rhizosphere microbiota. Nature 
Communications 9, 2738.

Huber W., Carey V.J., Gentleman R., Anders S., Carlson M., Carvalho B.S., ... Morgan M. (2015)

Orchestrating high-throughput genomic analysis with Bioconductor. Nature Methods 12, 115-121.

in 't Zandt D., Hoekstra N.J., Wagemaker C.A.M., de Caluwe H., Smit-Tiekstra A.E., Visser E.J.W. \& de

Kroon H. (2020) Local soil legacy effects in a multi-species grassland community are underlain by root foraging and soil nutrient availability. Journal of Ecology, 10.1111/1365-2745.13449.

Kardol P., Cornips N.J., van Kempen M.M.L., Bakx-Schotman J.M.T. \& van der Putten W.H. (2007)

Microbe-mediated plant-soil feedback causes historical contingency effects in plant community assembly. Ecological Monographs 77, 147-162.

Kardol P., Martijn Bezemer T. \& Van Der Putten W.H. (2006) Temporal variation in plant-soil feedback controls succession. Ecology Letters 9, 1080-1088.

Kardol P., Souza L. \& Classen A.T. (2013) Resource availability mediates the importance of priority effects in plant community assembly and ecosystem function. Oikos 122, 84-94.

Kardol P., Veen G.F.C., Teste F.P. \& Perring M.P. (2015) Peeking into the black box: a trait-based approach to predicting plant-soil feedback. New Phytologist 206, 1-4.

Kassambara A. (2020) ggpubr: "ggplot2" Based Publication Ready Plots. R package version 0.4.0. https://CRAN.R-project.org/package=ggpubr.

Klironomos J.N. (2002) Feedback with soil biota contributes to plant rarity and invasiveness in communities. Nature 417, 67-70.

Kokla M., Virtanen J., Kolehmainen M., Paananen J. \& Hanhineva K. (2019) Random forest-based imputation outperforms other methods for imputing LC-MS metabolomics data: A comparative study. BMC Bioinformatics 20, 492.

Kong C.-H., Zhang S.-Z., Li Y.-H., Xia Z.-C., Yang X.-F., Meiners S.J. \& Wang P. (2018) Plant neighbor detection and allelochemical response are driven by root-secreted signaling chemicals. Nature Communications 9, 3867.

Korenblum E., Dong Y., Szymanski J., Panda S., Jozwiak A., Massalha H., ... Aharoni A. (2020) Rhizosphere microbiome mediates systemic root metabolite exudation by root-to-root signaling. Proceedings of the National Academy of Sciences of the United States of America 117, 38743883.

Körner C., Stöcklin J., Reuther-Thiébaud L. \& Pelaez-Riedl S. (2008) Small differences in arrival time 
bioRxiv preprint doi: https:/doi.org/10.1101/2020 09.01.276840; this version posted October 16, 2020. The copyright holder for this preprint (which was not certified by peer review) is the author/funder, who has granted bioRxiv a license to display the preprint in perpetuity. It is made available under aCC-BY 4.0 International license.

influence composition and productivity of plant communities. New Phytologist 177, 698-705.

Kramer-Walter K.R., Bellingham P.J., Millar T.R., Smissen R.D., Richardson S.J. \& Laughlin D.C. (2016) Root traits are multidimensional: specific root length is independent from root tissue density and the plant economic spectrum. Journal of Ecology 104, 1299-1310.

Kuhl C., Tautenhahn R., Böttcher C., Larson T.R. \& Neumann S. (2012) CAMERA: An integrated strategy for compound spectra extraction and annotation of liquid chromatography/mass spectrometry data sets. Analytical Chemistry 84, 283-289.

Kursa M.B. \& Rudnicki W.R. (2010) Feature selection with the boruta package. Journal of Statistical Software 36, 1-13.

Lange M., Eisenhauer N., Sierra C.A., Bessler H., Engels C., Griffiths R.I., .. Gleixner G. (2015) Plant diversity increases soil microbial activity and soil carbon storage. Nature Communications 6, 6707. Lê S., Josse J. \& Husson F. (2008) FactoMineR: An R package for Multivariate Analysis. Journal of Statistical Software 25, 1-18.

Lefcheck J.S. (2016) piecewiseSEM: Piecewise structural equation modelling in R for ecology, evolution, and systematics. Methods in Ecology and Evolution 7, 573-579.

Leff J.W., Bardgett R.D., Wilkinson A., Jackson B.G., Pritchard W.J., Long J.R. De, ... Fierer N. (2018) Predicting the structure of soil communities from plant community taxonomy, phylogeny, and traits. The ISME Journal 12, 1794-1805.

Lenth R. (2018) emmeans: Estimated Marginal Means, aka Least-Squares Means. R package version 1.4.3. https://CRAN.R-project.org/package=emmeans.

Liaw A. \& Wiener M. (2002) Classification and Regression by randomForest. $R$ News 2, 18-22.

MacArthur R. \& Levins R. (1967) The limiting similarity, convergence, and divergence of coexisting species. The American Naturalist 101, 377-385.

Mahall B.E. \& Callaway R.M. (1991) Root communication among desert shrubs. Proceedings of the National Academy of Sciences of the United States of America 88, 874-876.

Marion Z., Fordyce J. \& Fitzpatrick B. (2015a) hierDiversity: Hierarchical Multiplicative Partitioning of Complex Phenotypes. R package version 0.1. https://CRAN.R-project.org/package=hierDiversity. Marion Z.H., Fordyce J.A. \& Fitzpatrick B.M. (2015b) Extending the concept of diversity partitioning to characterize phenotypic complexity. The American Naturalist 186, 348-361.

Martin L.M. \& Wilsey B.J. (2012) Assembly history alters alpha and beta diversity, exotic-native 
proportions and functioning of restored prairie plant communities. Journal of Applied Ecology 49, $1436-1445$.

Mommer L., Cotton T.E.A., Raaijmakers J.M., Termorshuizen A.J., van Ruijven J., Hendriks M., ... Dumbrell A.J. (2018) Lost in diversity: the interactions between soil-borne fungi, biodiversity and plant productivity. New Phytologist 218, 542-553.

Mommer L., Kirkegaard J. \& van Ruijven J. (2016) Root-root interactions: towards a rhizosphere framework. Trends in Plant Science 21, 209-217.

Mommer L., van Ruijven J., De Caluwe H., Smit-Tiekstra A.E., Wagemaker C.A.M., Joop Ouborg N., ... de Kroon H. (2010) Unveiling below-ground species abundance in a biodiversity experiment: a test of vertical niche differentiation among grassland species. Journal of Ecology 98, 1117-1127. Mommer L., van Ruijven J., Jansen C., van de Steeg H.M. \& de Kroon H. (2012) Interactive effects of nutrient heterogeneity and competition: implications for root foraging theory? Functional Ecology 26, 66-73.

Mommer L., Visser E.J.W., van Ruijven J., de Caluwe H., Pierik R. \& de Kroon H. (2011) Contrasting root behaviour in two grass species: A test of functionality in dynamic heterogeneous conditions. Plant and Soil 344, 347-360.

Oburger E. \& Jones D.L. (2018) Sampling root exudates - Mission impossible? Rhizosphere 6, 116133.

Oburger E. \& Schmidt H. (2016) New methods to unravel rhizosphere processes. Trends in Plant Science 21, 243-255.

Padilla F.M., Mommer L., de Caluwe H., Smit-Tiekstra A.E., Wagemaker C.A.M., Ouborg N.J. \& de Kroon H. (2013) Early root overproduction not triggered by nutrients decisive for competitive success belowground. PLOS ONE 8, e55805.

Perry L.G., Alford E.R., Horiuchi J., Paschke M.W. \& Vivanco J.M. (2007) Chemical signals in the rhizosphere: root-root and root-microbe communication. In The rhizosphere: biochemistry and organic substances at the soil-plant interface. (eds R. Pinton, Z. Varanini \& P. Nannipieri), pp. 297-330. CRC Press, Boca Raton.

Peters K., Worrich A., Weinhold A., Alka O., Balcke G., Birkemeyer C., .. Dam N. (2018) Current Challenges in Plant Eco-Metabolomics. International Journal of Molecular Sciences 19, 1385. van der Putten W.H., Bardgett R.D., Bever J.D., Bezemer T.M., Casper B.B., Fukami T., ... Wardle D.A. 
(2013) Plant-soil feedbacks: the past, the present and future challenges. Journal of Ecology 101, 265-276.

R Core Team (2019) R: A language and environment for statistical computing. R Foundation for Statistical Computing, Vienna, Austria. URL http://www.r-project.org/.

R Core Team (2020) R: A language and environment for statistical computing. R Foundation for Statistical Computing, Vienna, Austria. URL http://www.r-project.org/.

Rillig M.C., Ryo M., Lehmann A., Aguilar-Trigueros C.A., Buchert S., Wulf A., ... Yang G. (2019) The role of multiple global change factors in driving soil functions and microbial biodiversity. Science $366,886-890$.

Ristok C., Poeschl Y., Dudenhöffer J., Ebeling A., Eisenhauer N., Vergara F., .. Weinhold A. (2019) Plant species richness elicits changes in the metabolome of grassland species via soil biotic legacy. Journal of Ecology 107, 2240-2254.

Rose L. (2017) Pitfalls in root trait calculations: how ignoring diameter heterogeneity can lead to overestimation of functional traits. Frontiers in Plant Science 8, 1-5.

Rose L. \& Lobet G. (2019) Accuracy of image analysis tools for functional root traits: A comment on Delory et al. (2017). Methods in Ecology and Evolution 10, 702-711.

Sasse J., Martinoia E. \& Northen T. (2018) Feed Your Friends: Do Plant Exudates Shape the Root Microbiome? Trends in Plant Science 23, 25-41.

Seethepalli A. \& York L.M. (2020) RhizoVision Explorer - Interactive software for generalized root image analysis designed for everyone (Version 2.0.0beta1). Zenodo. http://doi.org/10.5281/zenodo.3747698.

Semchenko M., Abakumova M., Lepik A. \& Zobel K. (2013) Plants are least suppressed by their frequent neighbours: the relationship between competitive ability and spatial aggregation patterns. Journal of Ecology 101, 1313-1321.

Semchenko M., Hutchings M.J. \& John E.A. (2007a) Challenging the tragedy of the commons in root competition: confounding effects of neighbour presence and substrate volume. Journal of Ecology 95, 252-260.

Semchenko M., John E.A. \& Hutchings M.J. (2007b) Effects of physical connection and genetic identity of neighbouring ramets on root-placement patterns in two clonal species. New Phytologist 176, 644-654. 
Semchenko M., Lepik A., Abakumova M. \& Zobel K. (2018) Different sets of belowground traits predict the ability of plant species to suppress and tolerate their competitors. Plant and Soil 424, 157169.

Semchenko M., Saar S. \& Lepik A. (2014) Plant root exudates mediate neighbour recognition and trigger complex behavioural changes. New Phytologist 204, 631-637.

Da Silva R.R., Dorrestein P.C. \& Quinn R.A. (2015) Illuminating the dark matter in metabolomics. Proceedings of the National Academy of Sciences of the United States of America 112, 12549 12550.

Smith C.A., Want E.J., O'maille G., Abagyan R. \& Siuzdak G. (2006) XCMS: Processing Mass Spectrometry Data for Metabolite Profiling Using Nonlinear Peak Alignment, Matching, and Identification. Analytical Chemistry 78, 779-787.

Solarik K.A., Cazelles K., Messier C., Bergeron Y. \& Gravel D. (2020) Priority effects will impede range shifts of temperate tree species into the boreal forest. Journal of Ecology 108, 1155-1173.

Stekhoven D.J. \& Bühlmann P. (2012) MissForest - Non-parametric missing value imputation for mixed-type data. Bioinformatics 28, 112-118.

Strehmel N., Böttcher C., Schmidt S. \& Scheel D. (2014) Profiling of secondary metabolites in root exudates of Arabidopsis thaliana. Phytochemistry 108, 35-46.

Stuble K.L. \& Souza L. (2016) Priority effects: natives, but not exotics, pay to arrive late. Journal of Ecology 104, 987-993.

Sun L., Ataka M., Han M., Han Y., Gan D., Xu T., ... Zhu B. (2020) Root exudation as a major competitive fine-root functional trait of 18 coexisting species in a subtropical forest. New Phytologist, nph.16865.

Tautenhahn R., Bottcher C. \& Neumann S. (2008) Highly sensitive feature detection for high resolution LC/MS. BMC Bioinformatics 9, 504.

Temperton V.M., Baasch A., von Gillhaussen P. \& Kirmer A. (2016) Assembly theory for restoring ecosystem structure and functioning: timing is everything? In Foundations of Restoration Ecology, Second. (eds M.A. Palmer, J.B. Zedler \& D.A. Falk), pp. 245-270. Island Press, Washington, DC. Uthe H., van Dam N.M., Hervé M.R., Sorokina M., Peters K. \& Weinhold A. (2021) A practical guide to implementing metabolomics in plant ecology and biodiversity research. In Advances in Botanical Research. 
Valverde-Barrantes O.J., Smemo K.A., Feinstein L.M., Kershner M.W. \& Blackwood C.B. (2013) The distribution of below-ground traits is explained by intrinsic species differences and intraspecific plasticity in response to root neighbours. Journal of Ecology 101, 933-942.

de Vries F.T., Williams A., Stringer F., Willcocks R., McEwing R., Langridge H. \& Straathof A.L. (2019) Changes in root-exudate-induced respiration reveal a novel mechanism through which drought affects ecosystem carbon cycling. New Phytologist 224, 132-145.

Wang N.-Q., Kong C.-H., Wang P. \& Meiners S.J. (2020) Root exudate signals in plant-plant interactions. Plant, Cell \& Environment.

Wasserstein R.L., Schirm A.L. \& Lazar N.A. (2019) Moving to a World Beyond "p < 0.05." The American Statistician 73, 1-19.

Weidlich E.W.A., von Gillhaussen P., Delory B.M., Blossfeld S., Poorter H. \& Temperton V.M. (2017) The importance of being first: exploring priority and diversity effects in a grassland field experiment. Frontiers in Plant Science 7, 1-12.

Weidlich E.W.A., von Gillhaussen P., Max J.F.J., Delory B.M., Jablonowski N.D., Rascher U. \& Temperton V.M. (2018) Priority effects caused by plant order of arrival affect belowground productivity. Journal of Ecology 106, 774-780.

Weidlich E.W.A., Nelson C.R., Maron J.L., Callaway R.M., Delory B.M. \& Temperton V.M. (2020) Priority effects and ecological restoration. EcoEvoRxiv, 10.32942/osf.io/tm5bk.

Werner C.M., Stuble K.L., Groves A.M. \& Young T.P. (2020) Year effects: Interannual variation as a driver of community assembly dynamics. Ecology, e03104.

Werner C.M., Vaughn K.J., Stuble K.L., Wolf K. \& Young T.P. (2016) Persistent asymmetrical priority effects in a California grassland restoration experiment. Ecological Applications 26, 1624-1632.

Wetzel W.C. \& Whitehead S.R. (2020) The many dimensions of phytochemical diversity: linking theory to practice. Ecology Letters 23, 16-32.

Wickham H. (2016) ggplot2: Elegant Graphics for Data Analysis. Springer-Verlag New York.

Williams A. \& de Vries F.T. (2019) Plant root exudation under drought: implications for ecosystem functioning. New Phytologist 225, 1899-1905.

Wilsey B. (2020) Restoration in the face of changing climate: importance of persistence, priority effects and species diversity. Restoration Ecology, rec.13132.

Wilsey B.J., Barber K. \& Martin L.M. (2015) Exotic grassland species have stronger priority effects than 
bioRxiv preprint doi: https://doi.org/10.1101/2020.09.01.276840; this version posted October 16, 2020. The copyright holder for this preprint (which was not certified by peer review) is the author/funder, who has granted bioRxiv a license to display the preprint in perpetuity. It is made available under aCC-BY 4.0 International license.

natives regardless of whether they are cultivated or wild genotypes. New Phytologist 205, 928937. 


\section{Supporting information}

$\square$ CTL Forbs $\square$ Grasses

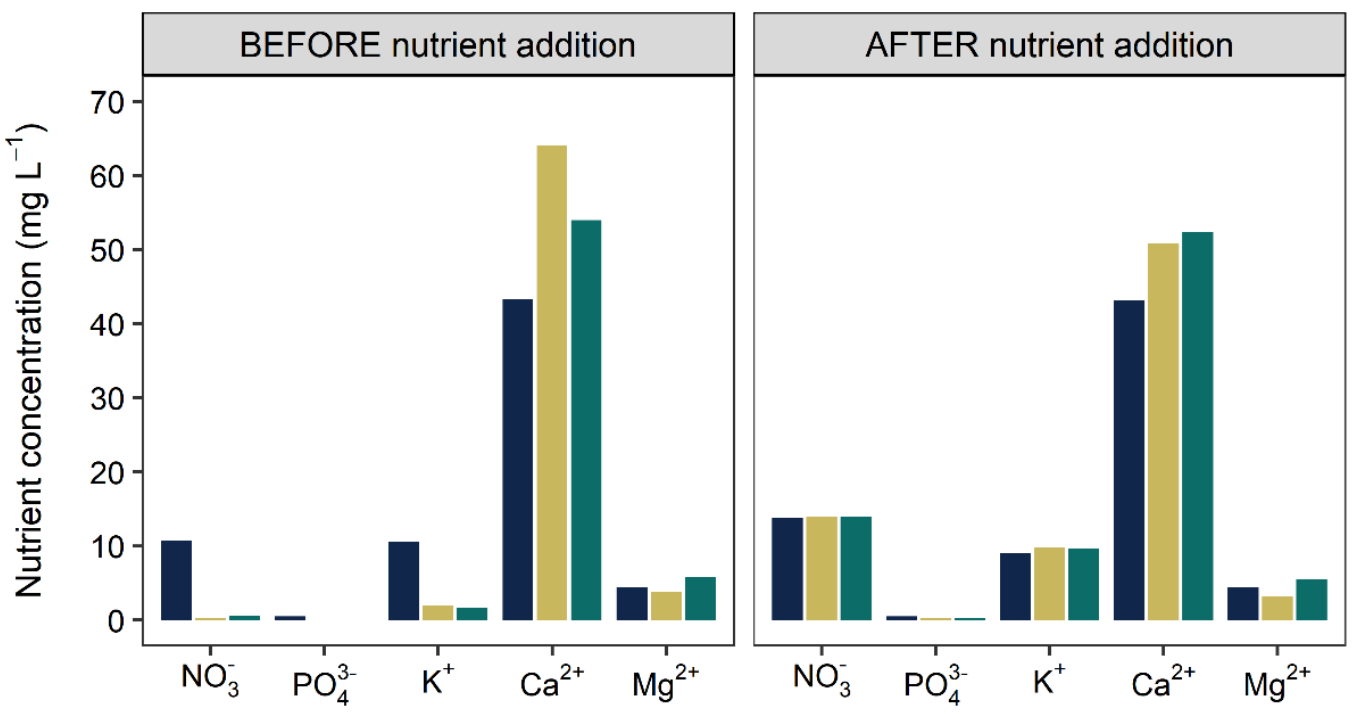

Fig. S1 Concentration of macronutrients in soil solution samples collected from CTL, Forbs, and Grasses mesocosms before and after addition of salts. $\mathrm{Ca}\left(\mathrm{NO}_{3}\right)_{2} \cdot 4 \mathrm{H}_{2} \mathrm{O}$ was added in $\mathrm{CTL}$ samples. $\mathrm{KNO}_{3}$ and $\mathrm{KH}_{2} \mathrm{PO}_{4}$ were added in Forbs and Grasses samples. 
(a)
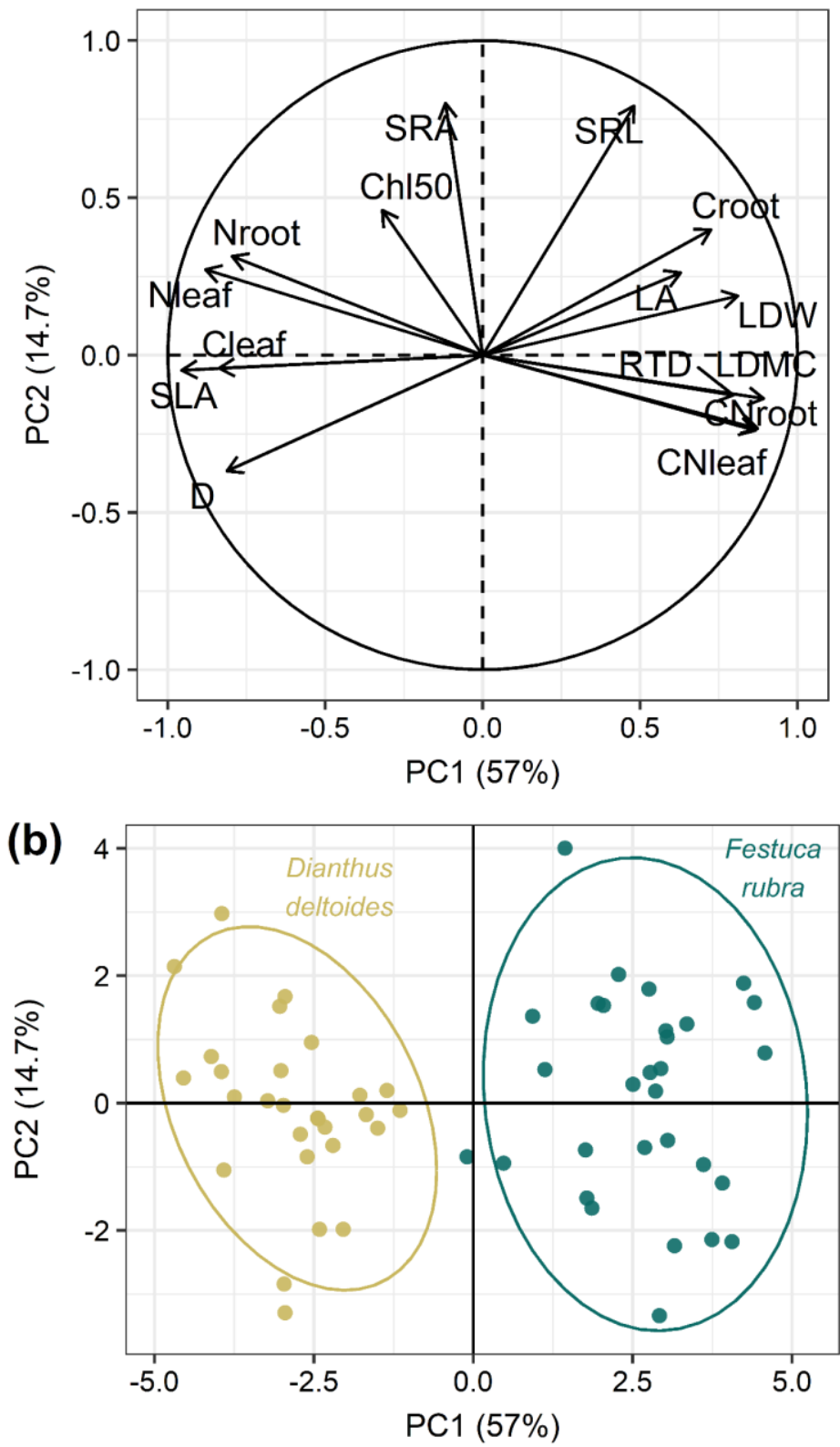

Fig. S2 Principal component analysis of plant functional traits measured on Dianthus deltoides and Festuca rubra. Panel (a) shows the correlation circle (each arrow represents a variable). Panel (b) shows the graph of individuals (each dot is a plant individual). D, root diameter; SLA, specific leaf area; Cleaf, leaf $\mathrm{C}$ concentration; Nleaf, leaf $\mathrm{N}$ concentration; Nroot, root $\mathrm{N}$ concentration; Chl50, leaf chlorophyll concentration; SRA, specific root area; SRL, specific root length; Croot, root $\mathrm{C}$ concentration; LA, leaf area; LDW, leaf dry weight; RTD, root tissue density; LDMC, leaf dry matter content; CNroot, root C:N ratio; CNleaf, leaf C: $\mathrm{N}$ ratio. 
bioRxiv preprint doi: https://doi. org/10.1101/2020.09.01276840: this version posted October 16,2020 . The copyright holder for this preprint (which was not certified by peer review) is the author/funder, who has granted bioRxiv a license to display the preprint in perpetuity. It is made available under aCC-BY 4.0 International license.

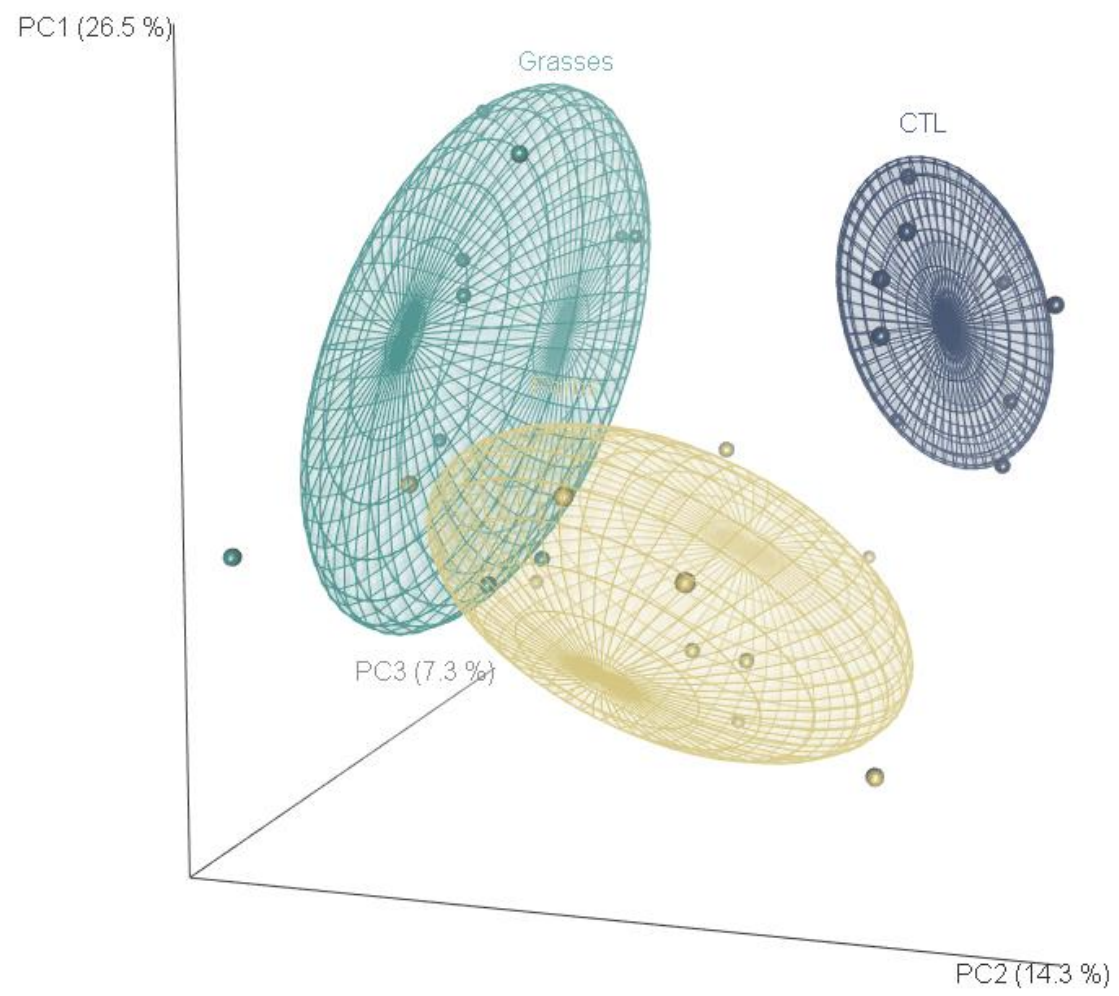

Fig. S3 Principal component analysis showing the position of each soil solution sample in 3D space. The first three principal components explain $26.5 \%, 14.3 \%$, and $7.3 \%$ of the total variance, respectively. In this graph of individuals, each dot is a soil solution sample. The metabolome profiles of CTL (soil only), Forbs, and Grasses solution samples are shown in blue, yellow, and green, respectively. 

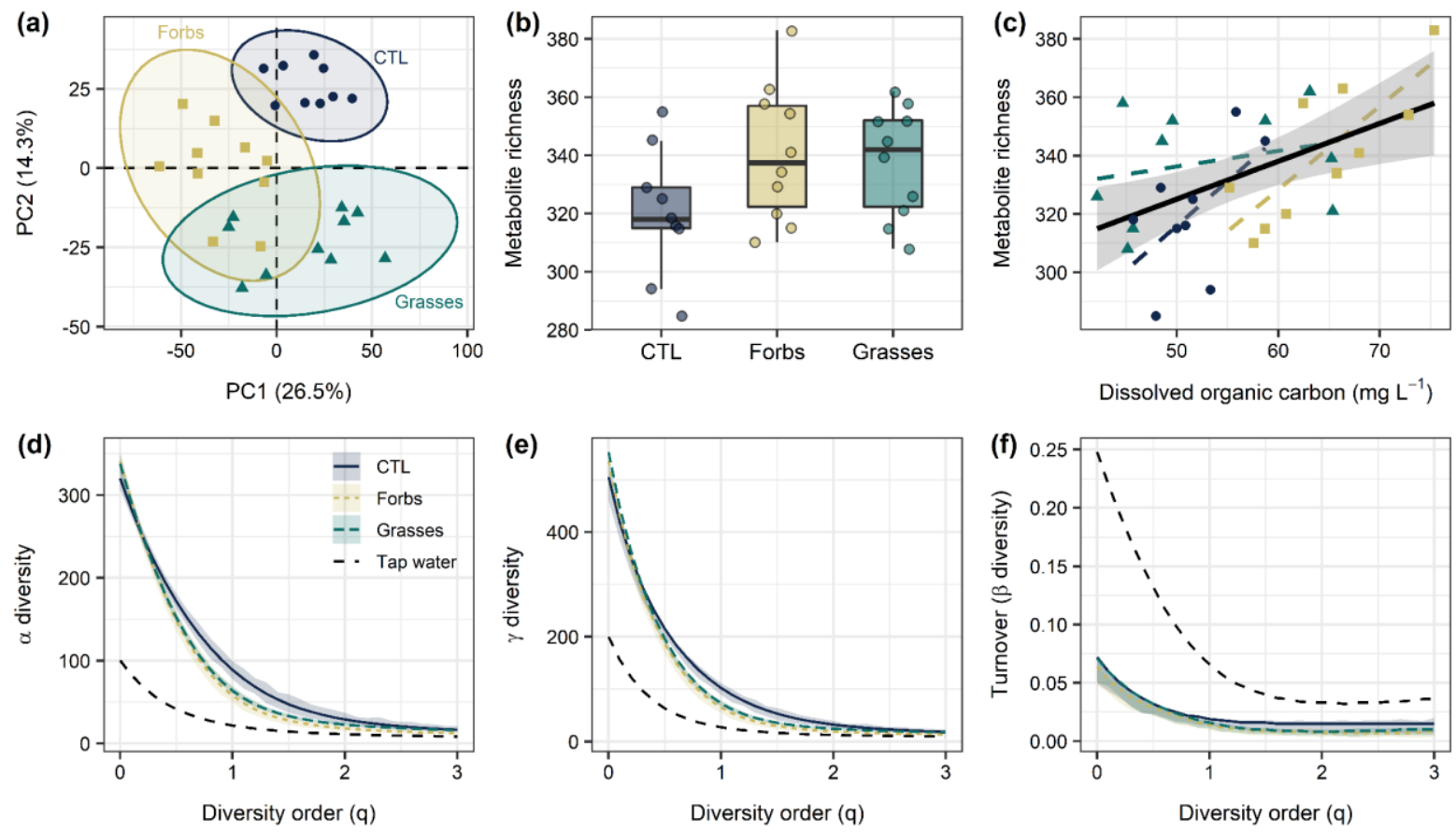

Fig. S4 Plant community composition affects the composition and chemical diversity of the metabolome found in the soil solution (negative mode). (a) Principal component analysis performed on a dataset containing both positive and negative ionisation data. (b) Differences in metabolite richness between soil solution samples collected from CTL, Forbs, and Grasses mesocosms (see Fig. 1). (c) Positive chemical diversity - abundance relationship. (d-f) Chemical diversity profile plots showing the decrease in effective $\alpha$-diversity (d), $\gamma$-diversity (e), and $\beta$-diversity (f) with increasing diversity order. Panels b-f rely solely on negative ionisation data. In panel $f$, turnover is a standardised estimate of $\beta$-diversity bounded between zero (samples are identical) and one (samples are completely different). In panels ac, each dot is an individual observation ( $n=9$ for CTL and $n=10$ for Forbs and Grasses). 

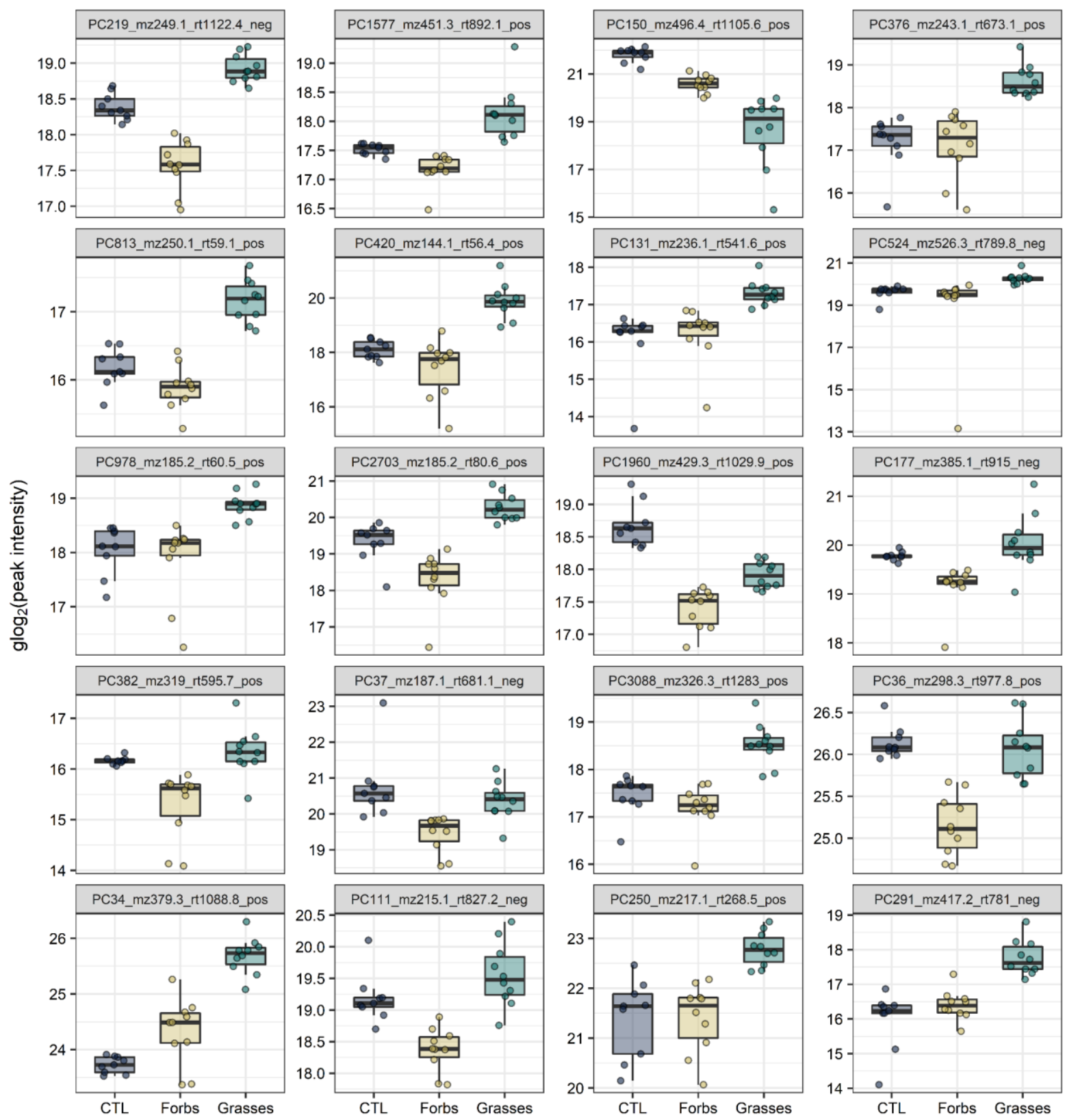

Fig. S5 Twenty most discriminant metabolites between soil solution samples collected from CTL, Forbs, and Grasses mesocosms. The most discriminant features were detected using a random forest approach (see Materials and Methods). Among these 20 metabolites, 14 were detected in positive ionisation mode and 6 were detected in negative ionisation mode. PC, pseudo compound; mz, massto-charge ratio; rt, retention time (s). 
bioRxiv preprint doi: https://doi.org/10.1101/2020.09.01.276840; this version posted October 16, 2020. The copyright holder for this preprint (which was not certified by peer review) is the author/funder, who has granted bioRxiv a license to display the preprint in perpetuity. It is made available under aCC-BY 4.0 International license.
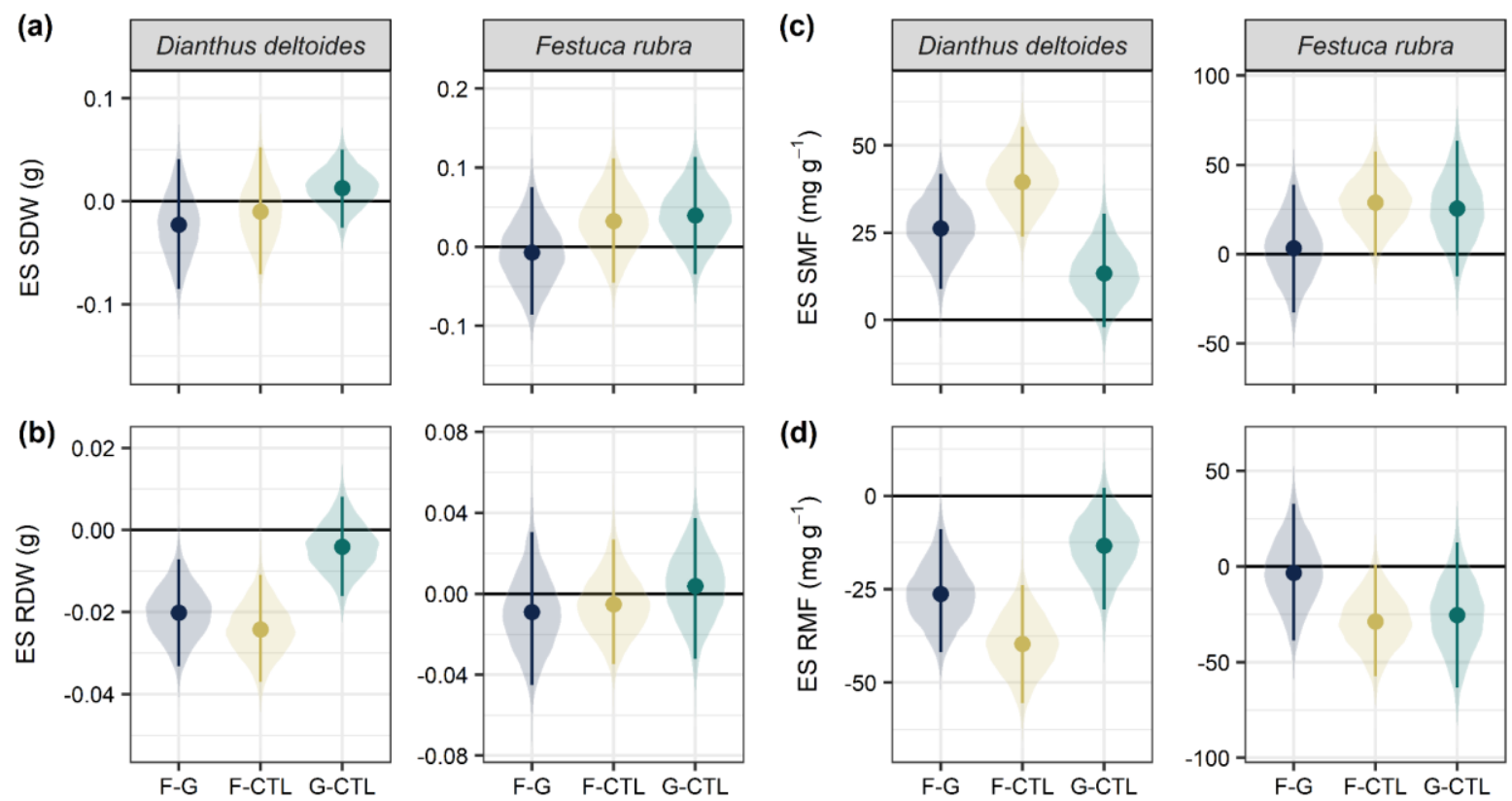

Fig. S6 Effect sizes and compatibility intervals calculated for shoot dry weight (a), root dry weight (b), shoot mass fraction (c), and root mass fraction (d). F-G, Forbs minus Grasses; F-CTL, Forbs minus CTL; G-CTL, Grasses minus CTL. Effect sizes were calculated as the absolute difference between treatment means. Compatibility intervals were computed using a non-parametric bootstrap. 

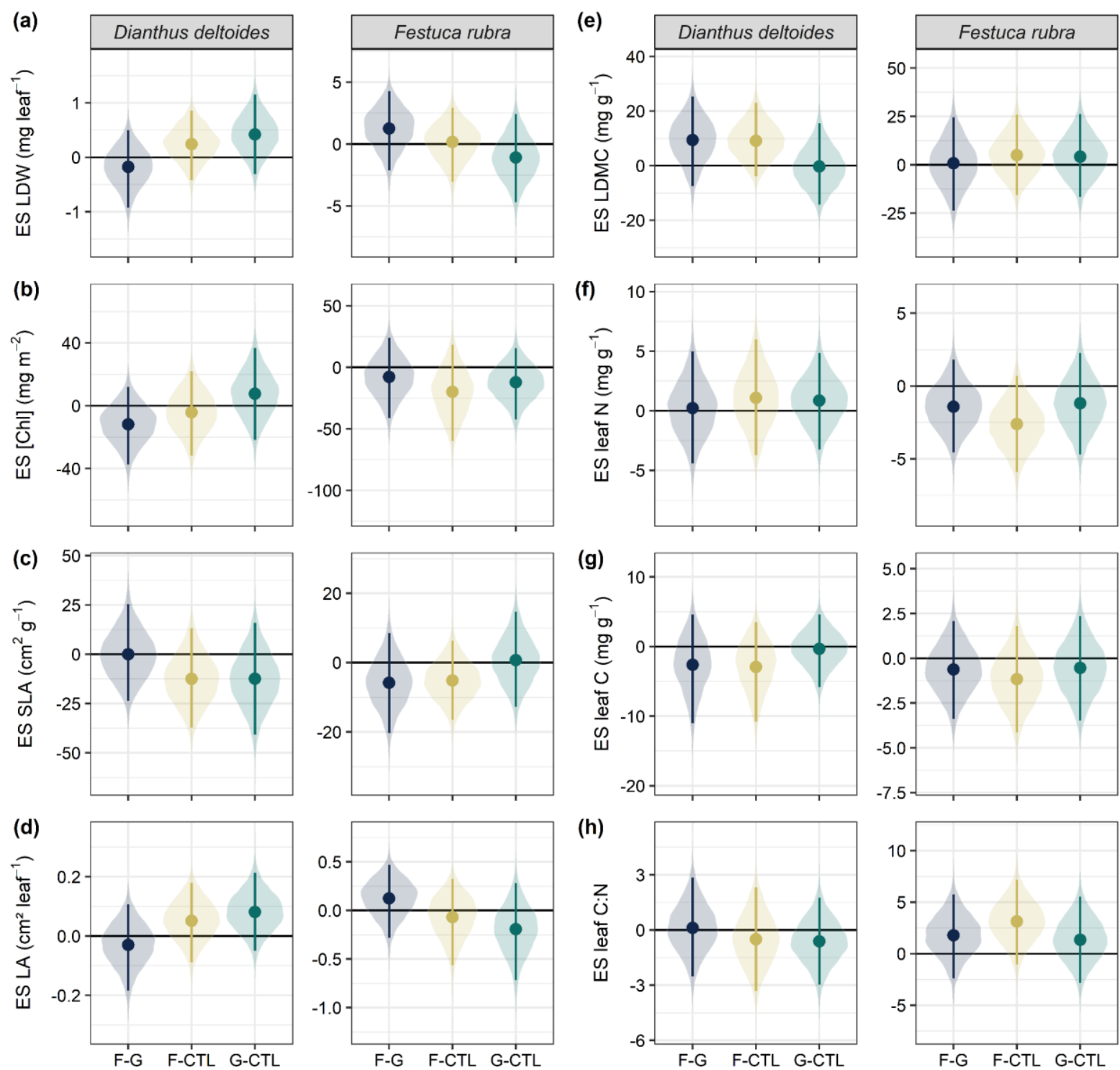

Fig. S7 Effect sizes and compatibility intervals calculated for leaf dry weight (a), leaf chlorophyll concentration (b), specific leaf area (c), leaf area (d), leaf dry matter content (e), leaf $\mathrm{N}$ concentration (f), leaf C concentration (g), and leaf C:N ratio (h). F-G, Forbs minus Grasses; F-CTL, Forbs minus CTL; G-CTL, Grasses minus CTL. Effect sizes were calculated as the absolute difference between treatment means. Compatibility intervals were computed using a non-parametric bootstrap. 


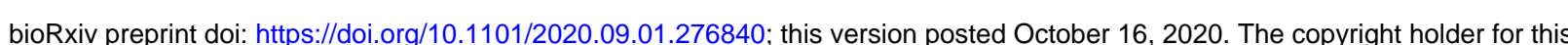
preprint (which was not certified by peer review) is the author/funder, who has granted bioRxiv a license to display the preprint in perpetuity. It is made available under aCC-BY 4.0 International license.
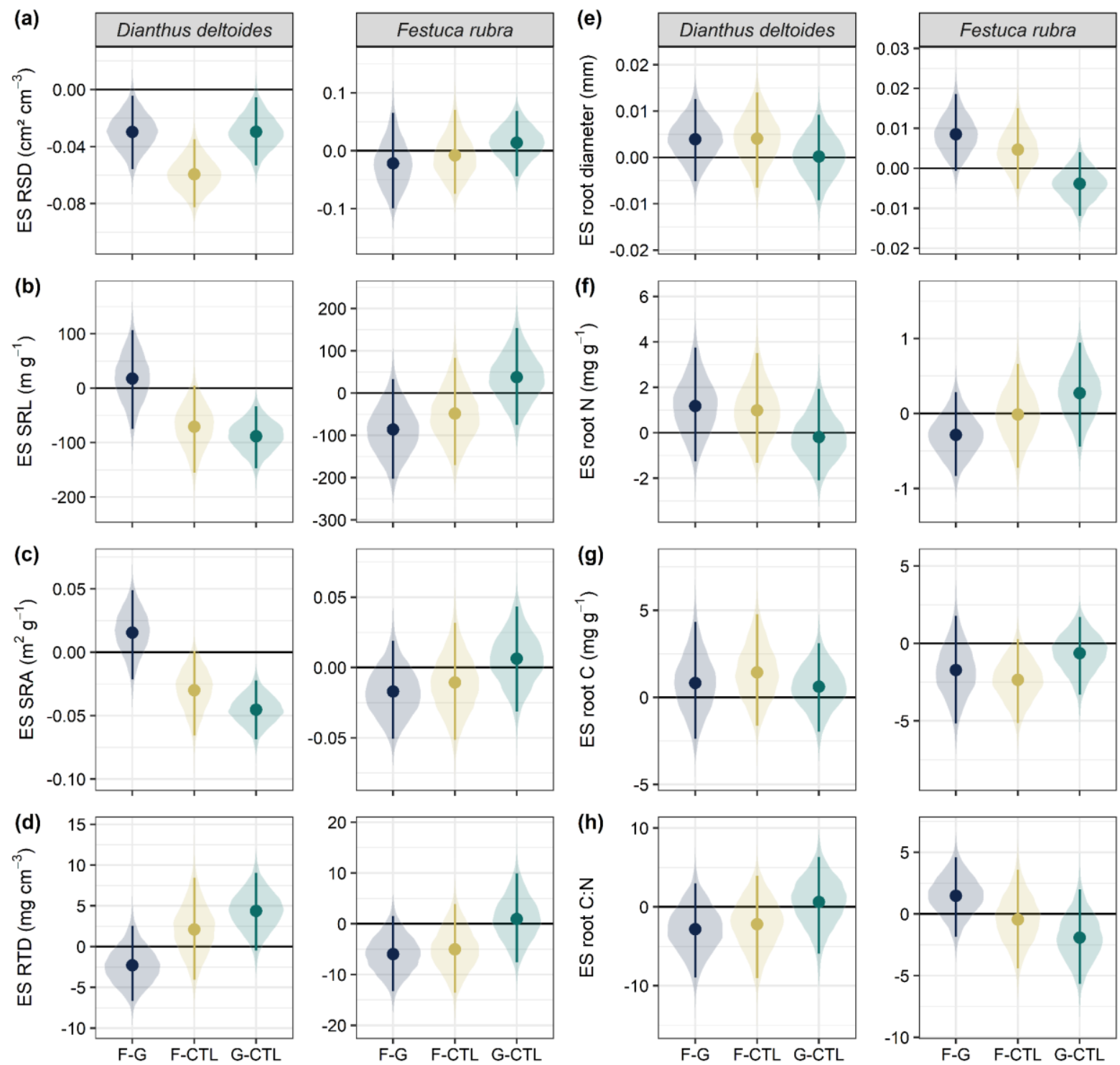

Fig. S8 Effect sizes and compatibility intervals calculated for root surface density (a), specific root length (b), specific root area (c), root tissue density (d), root diameter (e), root $\mathrm{N}$ concentration (f), root $\mathrm{C}$ concentration (g), and root C:N ratio (h). F-G, Forbs minus Grasses; F-CTL, Forbs minus CTL; G-CTL, Grasses minus CTL. Effect sizes were calculated as the absolute difference between treatment means. Compatibility intervals were computed using a non-parametric bootstrap. 